Reiter, M. E., E. Palacios, D. Eusse-Gonzalez, R. Johnston, P. Davidson, D. W. Bradley, R. Clay, K. M. Strum, J. Chu, B. A. Barbaree, C. M. Hickey, D. B. Lank, M. Drever, R. C. Ydenberg, and R. Butler. 2020. A monitoring framework for assessing threats to nonbreeding shorebirds on the Pacific Coast of the Americas. Avian Conservation and Ecology 15(2):7. https://doi.org/10.5751/ACE-01620-150207

Copyright (C) 2020 by the author(s). Published here under license by the Resilience Alliance.

Research Paper

\title{
A monitoring framework for assessing threats to nonbreeding shorebirds on the Pacific Coast of the Americas
}

\author{
Matthew E. Reiter ${ }^{1}$, Eduardo Palacios ${ }^{2}$, Diana Eusse-Gonzalez ${ }^{3}$, Richard Johnston González ${ }^{3,4}$, Pete Davidson ${ }^{5}$, David W. Bradley ${ }^{5}$, \\ Rob Clay ${ }^{6}$, Khara M. Strum ${ }^{7}$, James Chu ${ }^{8}$, Blake A. Barbaree ${ }^{1}$, Catherine M. Hickey ${ }^{1}$, David B. Lank ${ }^{4}$, Mark Drever ${ }^{9}$, Ronald C. \\ Ydenberg ${ }^{4}$ and Robert Butler ${ }^{10}$ \\ ${ }^{1}$ Point Blue Conservation Science, ${ }^{2}$ Centro de Investigación Científica y de Educación Superior de Ensenada, Baja California, Unidad \\ La Paz, ${ }^{3}$ Asociación para el estudio y la conservación de las aves Acuáticas en Colombia - Calidris, ${ }^{4}$ Centre for Wildlife Ecology, \\ Simon Fraser University, ${ }^{5}$ Birds Canada, ${ }^{6}$ WHSRN Executive Office, Manomet, ${ }^{7}$ Audubon California, ${ }^{8}$ United States Forest Service \\ International Programs, ${ }^{9}$ Environment and Climate Change Canada, ${ }^{10}$ Pacific WildLife Foundation
}

\begin{abstract}
Many shorebirds (Order: Charadriiformes; Family: Charadriidae, Recurvirostridae, Scolopacidae, Haematopodidae, Jacanidae) are highly migratory, traversing thousands of kilometers between high latitude breeding and low latitude nonbreeding sites. In doing so, they are dependent on networks of coastal and interior wetland ecosystems. To aid in the effective conservation and management of their populations, and to assess the impact of threats facing shorebirds, standardized data on shorebird abundance are needed from multiple sites representing a gradient of conditions across the hemisphere. Such data would provide insight on whether fluctuations at one location represent real changes in abundance because of some localized threat, or whether other factors acting across broader scales such as the redistribution of predators, are responsible. We designed the Migratory Shorebird Project (MSP), now implemented in 11 countries along the Pacific Coast of the Americas, to characterize spatial and temporal variation in shorebird abundance, to understand which factors (habitat, threats) most influence their populations across the flyway, and to increase capacity for integrated research, monitoring, and conservation. We used bird inventory data from historical surveys and spatial data on habitat distribution along with a set of hypotheses about important threats to guide the design of the project and to identify data requirements to test hypotheses. We counted birds one time per year at 84 nonbreeding sites ( 1400 sampling units) between 15 November and 15 February, when shorebirds were relatively stationary. In each of the first three annual counts from 2013/14 to 2015/16, the Migratory Shorebird Project counted $\sim 1 \mathrm{M}$ shorebirds representing 44 species, including five species for which $>20 \%$ of the estimated biogeographic population was recorded annually, and nine additional species with $>5 \%$ recorded annually. The magnitude of variability in estimates of shorebird abundance was inversely correlated with survey effort with the most uncertainty, and lowest survey effort, in the South Temperate region followed by the Neotropical region (southern Mexico to northern Peru) and then the North Temperate region. Evaluation of variance highlighted both among-site and among-unit ("units" are nested within sites) variation in bird abundance and cover types as well as threats such as potential disturbance and predator abundance. Overall, shorebird density was significantly, and positively, associated with the area (ha) of intertidal mudflats, beaches, and aquaculture. Survey units with intermediate levels of bare ground and flooding had the highest shorebird density. As for threats, we found, contrary to our hypothesis, that shorebird abundance was significantly, and positively, associated, with the density of Peregrine Falcons (Falco peregrinus); however we found no relationship between shorebird abundance and the amount of urban development, our index to potential human disturbance, in the surrounding landscape. The Migratory Shorebird Project is providing an essential data foundation and network for increased knowledge of the factors affecting shorebirds across the Pacific Coast of the Americas and identifying what and where conservation actions could have the greatest impact.
\end{abstract}

\section{Un cadre de surveillance pour évaluer les menaces pesant sur les oiseaux de rivage non reproducteurs sur la côte pacifique des Amériques}

RÉSUMÉ. De nombreux oiseaux de rivage (Ordre : Charadriiformes; Famille : Charadriidae, Recurvirostridae, Scolopacidae, Haematopodidae, Jacanidae) sont de grands migrateurs, parcourant des milliers de kilomètres entre les sites de reproduction à hautes latitudes et les sites hors reproduction à basses latitudes. Ce faisant, ils dépendent de réseaux d'écosystèmes de zones humides côtières et intérieures. Pour contribuer à la conservation et à la gestion efficaces de leurs populations, et évaluer l'impact des menaces qui pèsent sur eux, il est nécessaire de disposer de données normalisées sur leur abondance provenant de multiples sites représentant un gradient de conditions à travers l'hémisphère. Ces données permettraient de savoir si les fluctuations à un endroit donné représentent de réels changements dans l'abondance en raison d'une menace localisée ou si d'autres facteurs agissant à des échelles plus grandes, comme la redistribution des prédateurs, en sont responsables. Nous avons conçu le Projet sur les oiseaux de rivage migrateurs (Migratory Shorebird Project [MSP] en anglais), actuellement mis en oeuvre dans 11 pays de la côte pacifique des Amériques, afin de caractériser les variations spatiales et temporelles de l'abondance des oiseaux de rivage, de comprendre quels facteurs (habitats, menaces) influencent le plus leurs populations sur la voie de migration, et d'accroître la capacité de recherche intégrée, de surveillance et de conservation. Nous avons utilisé 
des données d'inventaire d'oiseaux provenant de relevés historiques et des données spatiales sur la répartition des habitats ainsi qu'un ensemble d'hypothèses sur les menaces importantes pour guider la conception du projet et identifier les besoins en données afin de tester les hypothèses. Nous avons dénombré les oiseaux une fois par an sur 84 sites hors reproduction ( 1400 unités d'échantillonnage) entre le 15 novembre et le 15 février, lorsque les oiseaux de rivage étaient relativement stationnaires. À chacun des trois premiers comptages annuels de 2013-14 à 2015-16, le MSP a dénombré environ 1 million d'oiseaux de rivage représentant 44 espèces, dont cinq espèces pour lesquelles $>20 \%$ de la population biogéographique estimée a été enregistrée chaque année, et neuf autres espèces pour lesquelles $>5 \%$ a été enregistrée chaque année. L'ampleur de la variabilité des estimations de l'abondance des oiseaux de rivage était inversement corrélée à l'effort d'inventaire; la plus grande incertitude et l'effort d'inventaire le plus faible ont été observés dans la région tempérée du Sud, suivie de la région Néotropicale (du sud du Mexique au nord du Pérou), puis de la région tempérée du Nord. L'évaluation de la variance a mis en évidence la variation de l'abondance des oiseaux et des types de couverts, ainsi que les menaces telles que les perturbations potentielles et l'abondance des prédateurs, à la fois entre les sites et entre les unités (les « unités 》 sont situées dans les sites). Dans l'ensemble, la densité des oiseaux de rivage a été associée de manière significative et positive à la superficie (ha) des vasières intertidales, des plages et de l'aquaculture. Les unités d'inventaire présentant des niveaux intermédiaires de sol nu et d'inondation présentaient la plus forte densité d'oiseaux de rivage. En ce qui concerne les menaces, nous avons constaté, contrairement à notre hypothèse, que l'abondance des oiseaux de rivage était significativement et positivement associée à la densité de Faucons pèlerins (Falco peregrinus); cependant, nous n'avons trouvé aucune relation entre l'abondance des oiseaux de rivage et l'importance du développement urbain, notre indice de perturbation humaine potentielle, dans le paysage environnant. Le MSP fournit une base de données et un réseau essentiels pour mieux connaître les facteurs qui affectent les oiseaux de rivage sur la côte pacifique des Amériques et identifier les actions de conservation qui pourraient avoir le plus grand effet.

Key Words: conservation; habitat associations; hypothesized threats; monitoring network; Pacific Americas Flyway; shorebirds

\section{INTRODUCTION}

Wildlife population and biodiversity monitoring is essential for effective management and conservation of ecosystems (Green et al. 2005, Gitzen et al. 2012). However, many ecological processes and populations occur at geographic scales beyond the reach of traditional localized monitoring and research methods. Across the Pacific Coast of the Americas, most Nearctic-Neotropical migratory shorebirds (Order: Charadriiformes; Family: Charadriidae, Recurvirostridae, Scolopacidae, Haematopodidae, Jacanidae) are highly mobile animals that traverse thousands of kilometers biannually and are reliant upon a network of coastal and interior wetland ecosystems (Senner et al. 2016). The Pacific Coast of the Americas (Alaska to Chile) supports entire subspecies of several Nearctic-Neotropical migratory shorebird species, such as Pacific Dunlin (Calidris alpina pacifica) and Western Snowy Plover (Charadrius nivosus nivosus), and many locations have been designated as regionally, internationally, or hemispherically important for shorebirds by the Western Hemisphere Shorebird Reserve Network (http://www.whsrn. org/).

Many shorebird populations in the Western Hemisphere appear to be declining (Brown et al. 2001, USSCPP 2016). The extent of these declines is uncertain and their causes are not well understood, in part because of a lack of data, and particularly for populations along the Pacific Americas Flyway. Several threats hypothesized to be most contributing to declining shorebird populations include reduction in nonbreeding habitat availability (Senner et al. 2016); exposure to contaminants and pollutants (Strum et al. 2010); increased human disturbance (Peters and Otis 2007, Senner et al. 2016); climate change (Galbraith et al. 2002, Gardali et al. 2012, Senner at al. 2016); and increasing predator populations (Butler et al. 2003, Lank et al. 2003). However, there are major gaps in our understanding of which factors have the greatest influence on shorebird demographic rates and subsequently their populations (Fernández et al. 2010a, $b$, Senner et al. 2016).
The hypothesized threats to shorebirds may be encountered anywhere in their annual cycle (arctic breeding grounds, migratory stop-over sites, wintering sites) and the importance of threats may vary across shorebird populations and their associated habitats. For example, in the Upper Bay of Panama, tidal mudflat loss through urbanization is a primary threat to shorebirds (Senner et al. 2016); however changes to water supplies and exposure to contaminants may be the most significant threats to shorebirds in agricultural habitats (Strum et al. 2010, Reiter et al. 2018). Given their wide-ranging ecology, effectively monitoring the response of shorebird populations to these threats has not been possible at scales larger than an individual site, making the consequences of site-level threats difficult to quantify at a population level. Accordingly, multiscale assessments of migratory shorebird populations are needed to develop optimal conservation strategies based on site-specific vulnerabilities (Martin et al. 2007, Iwamura et al. 2013).

The tendency of many shorebird species to concentrate in a few locations across the hemisphere during the boreal winter (December-February), likely a result of aggregated food resources (Morrison 1984) and protection from predators (Page and Whitacre 1975), increases their vulnerability to threats at individual sites. Their ability to respond to changing habitat conditions over a large spatial extent (e.g., Warnock et al. 1995) makes quantifying the population impacts of local changes and threats difficult (Bart et al. 2007). Shorebird counts at a single wintering or migration stop-over site can give a biased view of population trends (Bart et al. 2007) and overall habitat conditions. For example, a decline in shorebirds using a specific site could be the result of a declining population across the range, a large-scale shift in species distribution while the overall population is stable, or declining habitat quality at the specific site. To discern local versus landscape-scale changes and the mechanisms driving these changes requires a regular assessment of variation in the distribution and abundance of shorebirds as well as the location and condition of shorebird habitat within and between sites over a large spatial extent using standardized protocols (Bart et al. 2005, Xu et al. 2015). 
We developed a monitoring network for shorebirds on their nonbreeding grounds along the Pacific Americas Flyway to improve our ability to understand the relative importance of threats and inform management and conservation of their habitat. The framework relies on collaboration among organizations that are currently researching, monitoring, managing, or conserving shorebirds (Dickinson et al. 2010, Sutherland et al. 2012) and leverages the design and implementation of The Pacific Flyway Shorebird Survey in California and northern Baja California, Mexico (Reiter et al. 2011a, b, Reiter et al. 2012), and the British Columbia Coastal Waterbird Survey (Crewe at al. 2012). The Migratory Shorebird Project (MSP or Project) is an international monitoring network for shorebirds on the Pacific Coast of the Americas, with the specific objectives to (1) quantify spatial and temporal trends in distribution and abundance of nonbreeding shorebirds from the individual site level, e.g., Fraser River Delta, to the geopolitical level, e.g., Baja California, to the flyway scale, the Pacific Americas Flyway (Fig. 1); (2) evaluate specific hypotheses about the factors influencing shorebird populations including habitat loss, climate change, human disturbance, and predators; (3) apply data to inform management and conservation decisions at multiple spatial scales; and (4) increase capacity of people and organizations to conduct shorebird research and conservation throughout the hemisphere.

Fig. 1. Regional delineations from Senner et al. (2016) and the nonbreeding range boundaries of Dunlin (Calidris alpina) and Western Sandpiper (C. mauri; left panel) and the project area and location of wetland sites included in the Migratory Shorebird Project (2013-2016) along the Pacific Coast of the America (right panel).

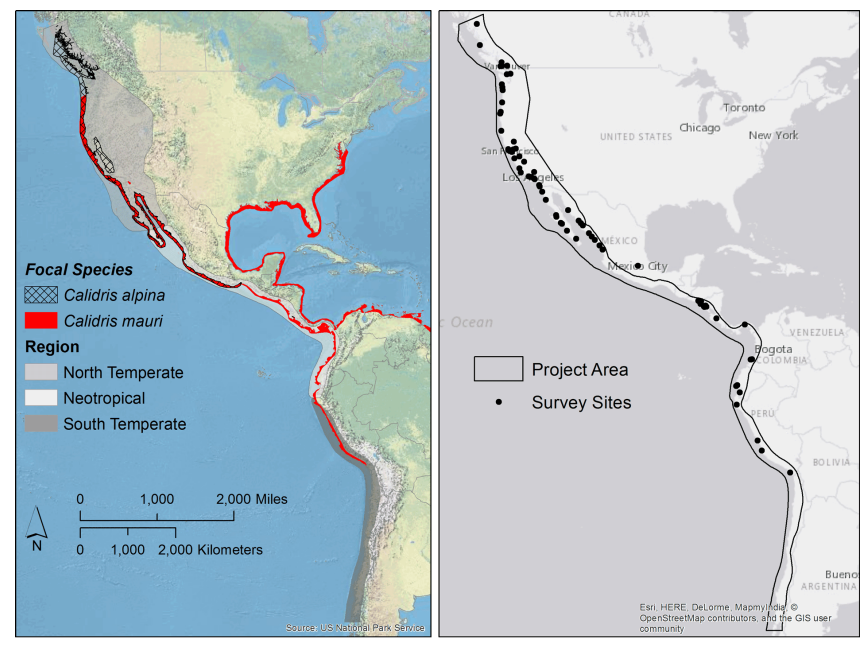

Here we describe the design of the MSP and report initial data and findings from the first three years (2013-2016) of surveys. Specifically, we (1) characterized sources of variance related to our protocols, (2) assessed the performance of our sampling design at capturing variation in threats and habitat, (3) quantified habitat associations, and (4) evaluated associations between shorebird abundance and two specific threats: predators and human disturbance.

\section{METHODS}

\section{Design}

\section{Defining the project area}

The Migratory Shorebird Project targets and collects data on all shorebird species that occur along the Pacific Coast of the Americas (Table 1; Fig. 1) with two focal species; Western Sandpiper (Calidris mauri) and Dunlin. We focused on these species because (1) they are abundant and widespread along the Pacific Coast of the Americas; (2) they breed in the Arctic so getting trends on the breeding grounds is challenging, (3) they are a good indicator of interior freshwater and saline wetlands as well as coastal intertidal wetlands, which support the highest diversity of shorebirds relative to other habitats; and (4) there is a large body of literature to support development of relevant threat hypotheses. The Project focuses on shorebird populations during their nonbreeding season and surveys occurred within the nonmigratory window of 15 November to 15 February (hereafter, winter). We targeted this window for several reasons. First, winter (NovemberFebruary) and migration (July-October, March-May) are the periods with the greatest abundance of shorebirds along the Pacific Americas Flyway south of Alaska (Page et al. 1999). Second, during winter, the spatial distribution of shorebird populations is relatively stationary, particularly compared to migration, reducing variation among counts on different days. Third, wetlands receive the longest duration of continuous use by individual shorebirds ("winter residents") during winter, making these wetlands an essential component of the annual cycle (Morrison and Hobson 2004). Last, because many important nonbreeding sites are located near human population centers, e.g., San Francisco Bay and Upper Bay of Panama, there is opportunity to engage volunteers to gather the necessary data and to influence local land managers and conservation actions.

To delineate the spatial extent of the Project, we modified the three planning regions of Senner et al. (2016) to match wintering ranges of Western Sandpiper and Dunlin (NatureServe 2017) as well as available habitat along the Pacific Coast (Fig. 1). Because of differences in habitat and shorebird use between coastal and interior areas of the North Temperate region, we delineated an interior subregion. The interior subregion was composed of the Central Valley, Imperial Valley, and the Salton Sea in California.

Within the three regions, we largely defined our sampling frame based on the distribution of eight cover types likely used by migratory shorebirds: intertidal mudflats, salt marsh, aquaculture (i.e., salt and shrimp production ponds), beaches, mangroves, flooded agriculture, freshwater interior wetlands, and saline lakes (Table 2), though other cover types were also surveyed because of randomization in our sampling unit selection (see below), particularly in the interior subregion, e.g., orchards. We used National Wetland Inventory data (Wilen and Bates 1995), coastal cover type data for Mexico to Chile (Eusse et al. 2017), an intertidal mudflat data layer (Murray et al. 2019), as well as Central Valley landcover (Dybala et al. 2017) and historic water distribution data (Reiter et al. 2015) to guide identification of habitat across the Project area. Our design was not intended to monitor use of rockyintertidal or upland habitats by shorebirds, and we sampled a considerably smaller proportion of available sandy beaches in the Project area compared to other focal habitat types. Hence, Project 
Table 1. Shorebird species observed over three winter surveys (2013-2016) as part of the Migratory Shorebird Project including average total birds counted per year at coastal and interior sites as well as the proportion of Pacific Flyway or hemisphere population being counted each year. Totals in parentheses are estimates of species of small sandpipers after allocating mixed species flocks.

\begin{tabular}{|c|c|c|c|c|c|}
\hline Species & Scientific Name & Coast & Interior & Total & \%pop \\
\hline Black-winged Stilt & Himantopus himantopus & 10 & 0 & 10 & \\
\hline Black-necked Stilt $^{\dagger}$ & Himantopus mexicanus & 10,341 & 4070 & 14,411 & 8 \\
\hline American Avocet ${ }^{\dagger}$ & Recurvirostra americana & 45,084 & 2837 & 47,920 & 11 \\
\hline American Oystercatcher & Haematopus palliatus & 573 & 0 & 573 & 5 \\
\hline Black Oystercatcher & Haematopus bachmani & 234 & 0 & 234 & 2 \\
\hline Southern Lapwing & Vanellus chilensis & 48 & 0 & 48 & \\
\hline Black-bellied Plover ${ }^{\dagger}$ & Pluvialis squatarola & 20,924 & 1462 & 22,386 & 22 \\
\hline American Golden-Plover & Pluvialis dominica & 7 & 0 & 7 & $<1$ \\
\hline Pacific Golden-Plover & Pluvialis fulva & 3 & 0 & 3 & $<1$ \\
\hline Collared Plover & Charadrius collaris & 51 & 0 & 51 & \\
\hline Snowy Plover ${ }^{\dagger}$ & Charadrius nivosus & 1436 & 202 & 1638 & 8 \\
\hline Wilson's Plover $^{\dagger}$ & Charadrius wilsonia & 1822 & 0 & 1822 & 21 \\
\hline Semipalmated Plover & Charadrius semipalmatus & 9334 & 47 & 9381 & 5 \\
\hline Killdeer & Charadrius vociferus & 1370 & 903 & 2273 & $<1$ \\
\hline Mountain Plover & Charadrius montanus & 0 & 0 & 0 & $<1$ \\
\hline Whimbrel & Numenius phaeopus & 2756 & 47 & 2803 & 7 \\
\hline Long-billed Curlew & Numenius americanus & 5082 & 477 & 5559 & 4 \\
\hline Bar-tailed Godwit & Limosa lapponica & 0 & 0 & 0 & $<1$ \\
\hline Hudsonian Godwit & Limosa haemastica & 3 & 0 & 3 & $<1$ \\
\hline Marbled Godwit ${ }^{\dagger}$ & Limosa fedoa & 53,752 & 1695 & 55,447 & 33 \\
\hline Ruddy Turnstone & Arenaria interpres & 1046 & 0 & 1046 & \\
\hline Black Turnstone & Arenaria melanocephala & 747 & 0 & 747 & 1 \\
\hline Red Knot & Calidris canutus & 443 & 0 & 443 & 3 \\
\hline Surfbird & Calidris virgata & 244 & 0 & 244 & $<1$ \\
\hline Stilt Sandpiper & Calidris himantopus & 265 & 52 & 318 & $<1$ \\
\hline Sanderling & Calidris alba & 9228 & 59 & $\begin{array}{c}9287 \\
(16,435)\end{array}$ & 3 \\
\hline Dunlin $^{\dagger}$ & Calidris alpina & 149,949 & 3241 & $\begin{array}{c}153,190 \\
(162,954)\end{array}$ & 28 \\
\hline Baird's Sandpiper & Calidris bairdii & 119 & 0 & 119 & $<1$ \\
\hline Least Sandpiper & Calidris minutilla & 50,616 & 5418 & $\begin{array}{c}56,034 \\
(108,688)\end{array}$ & 8 \\
\hline Pectoral Sandpiper & Calidris melanotos & 5 & 0 & 5 & $<1$ \\
\hline Semipalmated Sandpiper & Calidris pusilla & 11,595 & 0 & $\begin{array}{c}11,595 \\
(15,893)\end{array}$ & 1 \\
\hline Western Sandpiper $^{\dagger}$ & Calidris mauri & 292,807 & 5920 & $\begin{array}{c}298,728 \\
(330,099)\end{array}$ & 9 \\
\hline Mixed Calidris & Calidris spp & 235,519 & 0 & 235,519 & $<1$ \\
\hline Western-Least Sandpiper & C. mauri/minutilla & 17,080 & 1051 & 18,131 & $<1$ \\
\hline Western-Least-Dunlin & C. mauri/minutillalalpina & 27,159 & 888 & 28,046 & $<1$ \\
\hline Wester Sandpiper-Dunlin & C. maurilalpina & 2292 & 0 & 2292 & $<1$ \\
\hline Short-billed Dowitcher & Limnodromus griseus & 4268 & 0 & 4268 & 1 \\
\hline Long-billed Dowitcher & Limnodromus scolopaceus & 307 & 901 & 1209 & $<1$ \\
\hline Dowitcher spp. & Limnodromus spp. & 29,100 & 4197 & 33,297 & 6 \\
\hline Wilson’s Snipe & Gallinago delicata & 151 & 152 & 303 & $<1$ \\
\hline Spotted Sandpiper & Actitis macularius & 1178 & 5 & 1184 & $<1$ \\
\hline Solitary Sandpiper & Tringa solitaria & 16 & 0 & 16 & $<1$ \\
\hline Wandering Tattler & Tringa incana & 0 & 0 & 0 & $<1$ \\
\hline Lesser Yellowlegs & Tringa flavipes & 483 & 19 & 502 & $<1$ \\
\hline Willet $^{\dagger}$ & Tringa semipalmata & 30,613 & 16,82 & 32,295 & 20 \\
\hline Greater Yellowlegs & Tringa melanoleuca & 1684 & 314 & 1998 & 1 \\
\hline Yellowlegs spp. & Tringa spp. & 85 & 145 & 229 & $<1$ \\
\hline Wilson's Phalarope & Phalaropus tricolor & 2557 & 0 & 2557 & $<1$ \\
\hline Red-necked Phalarope & Phalaropus lobatus & 20 & 3 & 23 & $<1$ \\
\hline Red Phalarope & Phalaropus fulicarius & 0 & 0 & 0 & $<1$ \\
\hline
\end{tabular}

Species with largest percentage of a biogeographic population detected and used in analysis.

data collected for certain species that regularly use or prefer nonfocal habitat types have limited power for broader inference and consist of relatively small portions of their populations (Table $1)$.

We combined the cover type (Wilen and Bates 1995, Reiter et al. 2015, Eusse et al. 2017, Dybala et al. 2017, Murray et al. 2019) and historic bird abundance (Morrison and Ross 1989, Morrison et al. 1998, Shuford et al. 1998, Page et al. 1999, Shuford et al. 2002, SEMARNAT 2008, Johnston-González and EusseGonzalez 2009, Johnston-González et al. 2010, Sandoval and Sanchez 2011, Senner and Angulo Protolango 2014) data as well as previously defined site boundaries to identify a population of sites across each region. In El Salvador, Honduras, and Nicaragua 
Table 2. Summary focal cover types recorded as part of the Migratory Shorebird Project along the Pacific Coast of the Americas. Sampling units were not always homogenous in their cover types.

\begin{tabular}{ll}
\hline \hline Cover Type & Description \\
\hline Intertidal Mudflat & $\begin{array}{l}\text { Areas of mud, largely free of vegetation that occur between mean low tide and mean } \\
\text { high tide. } \\
\text { Areas of salt tolerant vegetation that are inundated during most high tides. Generally } \\
\text { higher up the intertidal elevational prism than intertidal mudflats. } \\
\text { Areas of managed water, typically in ponds connected to the ocean, which support the } \\
\text { production of salt or shrimp. }\end{array}$ \\
peach & $\begin{array}{l}\text { Sandy beach areas that are inundated only at the highest tides. } \\
\text { Typically found in interior sites in North America. These wetlands are hydrologically }\end{array}$ \\
Freshwater wetlands & $\begin{array}{l}\text { Thanged and dominated by freshwater emergent vegetation. } \\
\text { There are several types of agricultural crops that have been shown to benefit wetland } \\
\text { dependent shorebirds when flooded, including rice, corn, and other field crops. } \\
\text { Interior bodies of water found in western North America that have high salinity levels. } \\
\text { Salton Sea is currently the only interior saline lake in our survey but is an essential } \\
\text { wintering site for shorebirds. }\end{array}$ \\
& $\begin{array}{l}\text { Salt-tolerant trees and shrubs found in intertidal areas. The northern and southern } \\
\text { extent of mangroves define the boundaries of the Neotropical region. }\end{array}$ \\
&
\end{tabular}

we worked with local partners to define the set of sites that had $>500$ birds since published data were not available. Sites often represented a mosaic of cover types, e.g. San Francisco Bay, though sometimes they were homogenous, e.g. Equasal salt works in Ecuador. Across the three regions we defined 148 coastal sites and 6 interior sites that had at least 500 total shorebirds on any previously published survey (Table 3 ).

Table 3. Summary of available and surveyed sites across the three regions defined by the Migratory Shorebird Project. Sites were those places that included $>500$ shorebirds on any historical survey. Totals in parentheses represent the number of available and surveyed sites in the interior subregion of the North Temperate Region.

\begin{tabular}{lccc}
\hline \hline & Surveyed & Available & $\%$ Surveyed \\
\hline North Temperate & $52(6)$ & $73(6)$ & 71 \\
Neotropical & 29 & 52 & 56 \\
South Temperate & 3 & 23 & 13 \\
Total & 84 & 148 & 57 \\
\hline
\end{tabular}

\section{Hypothesis framework}

To inform our sampling design and ensure that we measured characteristics of sites that would allow us to evaluate multiple hypotheses of factors influencing shorebird populations, we developed a "hypothesis framework" (Table 4, Appendix I). We considered five threats that have been hypothesized to most limit shorebird populations: changes in nonbreeding habitat availability (Senner et al. 2016); exposure to contaminants and pollutants (Strum et al. 2010); human disturbance (Peters and Otis 2007, Senner et al. 2016); climate change (Galbraith et al. 2002, Gardali et al. 2012, Senner at al. 2016); and increasing predator populations (Butler et al. 2003, Lank et al. 2003). For each possible threat, we developed hypotheses about how it would affect birds and subsequently the predicted response we would expect to see in the survey data. We used the hypothesis framework to help identify the data and data collection protocols that would be needed to effectively address each hypothesis. Distinctions were made between covariates needed to evaluate threats that could be measured through a field protocol and those that required other types of data, e.g., remotely sensed time series of land cover change. The spatial distribution of most threats was not known in advance so sampling specifically based on the distribution of threats was not possible.

\section{Survey design and field protocols}

We were not able to randomly sample the population of identified sites but sought to establish surveys at as many of the identified sites as possible; 84 sites between 2013 and 2016. Since our initial design some sites with $<500$ individuals counted annually in historic surveys have been added opportunistically $(n=6)$. We selected sampling units within sites (spatially defined areas where birds and habitat were surveyed) randomly in order to capture variation in our parameters of interest, e.g., birds, disturbance, habitat, predators. However this random sample of units was frequently restricted to roads or accessible areas (see below). This approach in theory enables us to address hypotheses from the hypothesis framework for our set of sites more effectively with observational data. Also by surveying widely and across a gradient of shorebird abundance within $(0->40,000$ per sampling unit) and across sites $(<500->300,000$ total shorebirds per site) we hoped to guard against frame bias, which can affect the interpretation of trend from these data (Bart et al. 2007, Heisey et al. 2010).

We developed three variations of sampling unit definition and selection, and field protocols to accommodate challenges associated with counting shorebirds in different habitats and landscapes: (1) coastal areas; (2) interior wetland habitats; and (3) interior areas with extensive agriculture. Two fundamental survey design and protocol components were consistent across all regions and sites: (1) the boundaries of the sampling units were spatially defined and remained consistent through time, and (2) tidal stage during the survey was standardized across years for each coastal site. All shorebird surveys were conducted from the edges of the sampling unit to limit research-related disturbance and we assumed that the probability of detection was $100 \%$. 
Table 4. Example of the hypothesis framework developed to guide the design of the Migratory Shorebird Project and field protocols. Threats considered in this portion are predators and human disturbance. $\mathrm{H}=$ hypothesis; $\mathrm{P}=$ prediction; $\mathrm{SD}=$ study design; $\mathrm{D}=$ data; GIS = covariates derived from GIS; Observation = covariates derived from field observations. Western Sandpiper, Calidris mauri; Dunlin, Calidris alpina. See Appendix 1 for the full hypothesis matrix.

\begin{tabular}{|c|c|c|}
\hline Threat & Hypothesis and Predictions & Design and Data \\
\hline \multirow[t]{3}{*}{ Predators } & $\begin{array}{l}\text { H: Increases in the abundance of birds of prey has resulted in } \\
\text { changes in migratory behavior of shorebirds and possibly } \\
\text { changes in use of wintering grounds. }\end{array}$ & $\begin{array}{l}\text { SD: Need sample of "safe" and "dangerous" sites (e.g., average } \\
\text { distance to shore for estuary as index of site safety). }\end{array}$ \\
\hline & $\begin{array}{l}\text { P: We predict higher use of sites with lower probability of } \\
\text { predator occurrence. }\end{array}$ & $\begin{array}{l}\text { D: Count predators: evaluate predator pressure variation among } \\
\text { sites. }\end{array}$ \\
\hline & $\begin{array}{l}\text { P: We predict higher use of large, open sites (i.e., safer) versus } \\
\text { small and dangerous sites. }\end{array}$ & $\begin{array}{l}\text { D: Calculate safety index for all estuary sites in Western sandpiper } \\
\text { and Dunlin wintering range. }\end{array}$ \\
\hline \multirow[t]{3}{*}{$\begin{array}{l}\text { Human } \\
\text { Disturbance }\end{array}$} & $\begin{array}{l}\text { H: Human disturbance at wintering sites reduces the time } \\
\text { available for shorebirds to accumulate fat for migration and } \\
\text { subsequently could impact survival and productivity. }\end{array}$ & $\begin{array}{l}\text { SD: Need sample of sites with varying levels of human } \\
\text { disturbance during winter. }\end{array}$ \\
\hline & & $\begin{array}{l}\text { D: Quantify "human disturbance" or surrogate for all wintering } \\
\text { sites. }\end{array}$ \\
\hline & $\begin{array}{l}\text { P: Density of wintering shorebirds will be greater at sites with } \\
\text { lower disturbance. }\end{array}$ & $\begin{array}{l}\text { GIS: housing density } \\
\text { GIS: population within distance buffer of estuary site } \\
\text { Observation: number people in sampling unit during annual } \\
\text { survey } \\
\text { Observation: number of disturbance flights and duration }\end{array}$ \\
\hline
\end{tabular}

Coastal wetlands: Within each surveyed coastal site (Table 5), we used available cover type data to define the sampling frame and to delineate sampling unit boundaries that encompassed an area with largely homogenous habitat. Sampling unit size varied because we attempted to capture complete patches of shorebird habitat when feasible, e.g., salt pond or mudflat (Fig. 2A). In some sites with long linear strips of the same cover type, e.g., beaches, that were too large to be effectively surveyed as a single unit, we divided the strip up into 1-2 km sections along the shore, e.g., Upper Bay of Panama (Kaufmann et al. 2018).

The amount of focal shorebird habitats within a coastal site or region determined our approach to selecting individual sampling units. For large coastal sites with many potential sampling units, such as San Francisco Bay, we used a stratified generalized random tessellation sample (GRTS; Stevens and Olsen 2004) and the "spsurvey" package (Kincaid and Olsen 2017) in R v.3.3 (C) The R Foundation for Statistical Computing) to randomly select $\sim 30 \%$ of the possible sampling units weighted based on historical data on bird distribution (Wood et al. 2010). Simulations found that because of the consistency of use of high use areas weighting by the natural logarithm of total birds could reduce bias and variance associated with population changes in San Francisco Bay. For smaller coastal sites, we surveyed all sampling units when possible.

We coordinated single annual counts of sampling units within each coastal site to be on the same day within a year and at the same tide level across years. Tide levels for surveys were determined by timing of historic surveys or using pilot surveys to identify an optimal window of time when birds are detectible. A two- to three-hour tidal window was typically selected, ideally when birds were foraging, and the tide was moving slowly ("neap"). To limit counting and identification errors in coastal wetlands, the maximum recommended observation distance was $325 \mathrm{~m}$.

Interior flooded agriculture: Interior flooded agriculture and other wetlands used by our focal species were concentrated in California; specifically in the Central Valley, Imperial Valley, and Salton Sea (Shuford et al. 1998, 2002). Habitats used by shorebirds in the interior subregion largely consist of managed seasonal and semipermanent wetlands, winter flooded agriculture, and saline lakes. Within agriculture, habitat during the winter months is primarily created by postharvest flooding of rice, and to a lesser extent corn, winter wheat, and other field crops (Elphick and Oring 1998, Shuford et al. 1998, Dybala et al. 2017). For the flooded agriculture landscape of the Central Valley, we defined our sampling frame to include only potential habitat that was flooded between November and January in at least $30 \%$ of years 2000-2010 (Reiter et al. 2015).

To sample flooded agriculture in the Central Valley, we established random survey routes in two stages. The first stage was a random sample of $9.66 \mathrm{~km}$ by $9.66 \mathrm{~km}$ township blocks (Public Land Survey System; https://catalog.data.gov/dataset/blm-nationalpublic-land-survey-system-polygons-national-geospatial-data-assetngda) that had $>10 \%$ of the area ( $\sim 900 \mathrm{ha})$ flooded in at least $30 \%$ of winters between 2000 and 2010 . The second stage was a randomly generated $16 \mathrm{~km}$ road transect that started along the nearest accessible road to a randomly selected point within the township block. Each road transect had 20 fixed radius $(161 \mathrm{~m})$ point counts at $0.8 \mathrm{~km}$ intervals resulting in, on average, surveys of 164 ha of each 9324 ha township block (Fig. 2B).

Managed wetlands: For managed wetlands in California's Central and Imperial Valleys, we first identified 29 federal wildlife refuges and state wildlife areas ("complexes") with managed wetlands. 
Avian Conservation and Ecology 15(2): 7

http://www.ace-eco.org/vol15/iss2/art7/

Table 5. Summary of sites and annual survey effort (units and area) as part of the Migratory Shorebird Project on the Pacific Coast of the Americas, including the total units and associated surveyed area (ha) defined for a site and the average effort per year 2013-2016.

\begin{tabular}{|c|c|c|c|c|c|c|}
\hline Region & Geopolitical & Site & $\begin{array}{l}\text { Total } \\
\text { Units }\end{array}$ & $\begin{array}{l}\text { Average Units } \\
\text { Surveyed }\end{array}$ & $\begin{array}{l}\text { Total Unit } \\
\text { Area (ha) }\end{array}$ & $\begin{array}{l}\text { Average Area } \\
\text { (ha) Surveyed }\end{array}$ \\
\hline North & Canada & North Coast & 4 & 3 & 679 & 428 \\
\hline \multirow[t]{53}{*}{ Temperate } & & Central Coast & 1 & 3 & 16 & 16 \\
\hline & & Sunshine Coast & 11 & 8 & 1915 & 1663 \\
\hline & & Lower Mainland & 60 & 45 & 5115 & 4374 \\
\hline & & Gulf Islands & 49 & 40 & 3278 & 2738 \\
\hline & & Vancouver Island & 69 & 52 & 9285 & 8070 \\
\hline & USA & North Puget Sound & 23 & 21 & 722 & 685 \\
\hline & & Dungeness Bay & 7 & 4 & 120 & 109 \\
\hline & & Grays Harbor & 22 & 18 & 1190 & 1084 \\
\hline & & Willapa Bay & 18 & 13 & 1058 & 520 \\
\hline & & Columbia River Estuary & 13 & 10 & 669 & 543 \\
\hline & & Yaquina Bay & 3 & 3 & 3245 & 325 \\
\hline & & Coos Bay & 26 & 16 & 692 & 412 \\
\hline & & Bandon Marsh & 8 & 8 & 125 & 125 \\
\hline & & Humboldt Bay & 2 & 2 & 8512 & 8512 \\
\hline & & Sacramento Valley ${ }^{\dagger}$ & 42 & 37 & 15127 & 14550 \\
\hline & & Delta $^{\dagger}$ & 24 & 13 & 1555 & 1048 \\
\hline & & Tomales Bay & 12 & 12 & 609. & 609 \\
\hline & & Suisun Marsh & 6 & 5 & 970 & 956 \\
\hline & & Point Reyes Esteros & 32 & 24 & 653 & 550 \\
\hline & & Bolinas Lagoon & 17 & 15 & 471 & 443 \\
\hline & & San Francisco Bay & 144 & 134 & 15669 & 14937 \\
\hline & & Grasslands ${ }^{\dagger}$ & 11 & 9 & 1714 & 1291 \\
\hline & & Elkhorn Slough & 10 & 10 & 461 & 461 \\
\hline & & Tulare Basin Wetlands ${ }^{\dagger}$ & 4 & 3 & 2098 & 1489 \\
\hline & & Morro Bay & 14 & 13 & 1645 & 1134 \\
\hline & & Guadalupe-Nipomo Dunes & 2 & 2 & 26 & 26 \\
\hline & & Piute Ponds ${ }^{\dagger}$ & 6 & 4 & 300 & 275 \\
\hline & & Santa Ynez River Mouth & 17 & 16 & 121 & 115 \\
\hline & & Mugu Lagoon & 11 & 11 & 1244 & 1244 \\
\hline & & Los Angeles River & 3 & 3 & 141 & 141 \\
\hline & & Malibu Lagoon & 1 & 1 & 11 & 11 \\
\hline & & Santa Monica Beach & 1 & 1 & 13 & 13 \\
\hline & & Zuma Beach & 1 & 1 & 36 & 36 \\
\hline & & Seal Beach NWR & 8 & 8 & 327 & 327 \\
\hline & & Bolsa Chica Wetlands & 5 & 2 & 300 & 242 \\
\hline & & Upper Newport Bay & 13 & 12 & 266 & 241 \\
\hline & & Salton $\mathrm{Sea}^{\dagger^{\dagger}}$ & 29 & 26 & 13231 & 12869 \\
\hline & & Mission Bay & 9 & 8 & 239 & 222 \\
\hline & & San Diego Bay & 115 & 106 & 694 & 666 \\
\hline & & Tijuana River Estuary & 7 & 6 & 164 & 147 \\
\hline & Mexico & Estero de Punta Banda & 6 & 5 & 225 & 216 \\
\hline & & Delta del Rio Colorado & 11 & 9 & 297 & 245 \\
\hline & & Bahia San Quintin & 22 & 21 & 349 & 328 \\
\hline & & Estero Santa Cruz & 5 & 5 & 478 & 478 \\
\hline & & Estero El Cardonal & 6 & 4 & 91. & 87 \\
\hline & & Estero Tastiota & 7 & 6 & 989 & 93 \\
\hline & & Laguna Guerrero Negro & 9 & 8 & 171 & 163 \\
\hline & & Laguna Ojo de Liebre & 26 & 24 & 1466 & 811 \\
\hline & & Estero El Tobari & 2 & 1 & 5 & 4 \\
\hline & & Laguna San Ignacio & 20 & 19 & 359 & 358 \\
\hline & & Yavaros & 3 & 3 & 28 & 28 \\
\hline & & El Delgadito & 6 & 5 & 158 & 154 \\
\hline & & Agiabampo & 10 & 8 & 429 & 419 \\
\hline \multirow[t]{9}{*}{ Neotropical } & & Bahia Magdalena & 27 & 26 & 602 & 591 \\
\hline & & Bahia Santa Maria & 8 & 5 & 351 & 302 \\
\hline & & Ensenada Pabellones & 6 & 3 & 316 & 195 \\
\hline & & Ensenada de La Paz & 12 & 8 & 178 & 112 \\
\hline & & Bahia Ceuta & 7 & 7 & 76 & 76 \\
\hline & & Estero de Urias & 6 & 5 & 411 & 306 \\
\hline & & Huizache-Caimanero & 7 & 6 & 44 & 42 \\
\hline & & Marismas Nacionales & 32 & 30 & 1294 & 1244 \\
\hline & & Lago de Texcoco ${ }^{\dagger}$ & 4 & 4 & 1578 & 1578 \\
\hline
\end{tabular}

(con'd) 


\begin{tabular}{|c|c|c|c|c|c|c|}
\hline & \multirow{4}{*}{ El Salvador } & Barra de Santiago & 1 & 1 & 19 & 19 \\
\hline & & La Libertad & 4 & 4 & 14 & 14 \\
\hline & & Jiquilisco-Jaltepeque & 10 & 10 & 152 & 152 \\
\hline & & Golfo de Fonseca & 34 & 34 & 325 & 325 \\
\hline & Honduras & Golfo de Fonseca & 15 & 13. & 3204 & 2389 \\
\hline & \multirow{7}{*}{ Nicaragua } & Golfo de Fonseca & 4 & 2 & 33 & 21 \\
\hline & & La Bayona & 1 & 1 & 16 & 16 \\
\hline & & Padre Ramos & 1 & 1 & 11 & 11 \\
\hline & & Rio Boqueron & 1 & 1 & 8 & 8 \\
\hline & & Salina Grande & 1 & 1 & 9 & 9 \\
\hline & & Buena Vista & 1 & 1 & 39 & 39 \\
\hline & & Puerto Sandino & 1 & 1 & 30 & 30 \\
\hline & Costa Rica & Nicoya Gulf & 28 & 28 & 36 & 36 \\
\hline & Panama & Bahia de Panama & 24 & 17 & 410 & 280 \\
\hline & \multirow[t]{2}{*}{ Colombia } & Bocana del Rio Iscuande & 9 & 5 & 250 & 116 \\
\hline & & PNN Sanquianga & 112 & 68 & 3883 & 3010 \\
\hline & \multirow[t]{2}{*}{ Ecuador } & Pacoa & 18 & 18 & 836 & 809 \\
\hline & & Mar Bravo & 14 & 13 & 413 & 402 \\
\hline & \multirow[t]{5}{*}{ Peru } & Tumbes & 2 & 2 & 31 & 31 \\
\hline & & Manglares de Sechura & 16 & 16 & 148 & 148 \\
\hline South & & Pantanos de Villa & 2 & 2 & 9 & 9 \\
\hline \multirow[t]{2}{*}{ Temperate } & & Reserva Nacional de Paracas & 24 & 24 & 729 & 729 \\
\hline & & Ite & 4 & 4 & 74 & 74 \\
\hline
\end{tabular}

Indicates interior sites.

Fig. 2. Maps of sampling units from three types of surveys implemented across the Migratory Shorebird Project. (A) Coastal sampling units in Paracas National Park, Peru. (B) Road route with fixed-radius sampling units in rice fields of Sacramento Valley, California. (C) Managed wetland survey routes with sampling units.
A

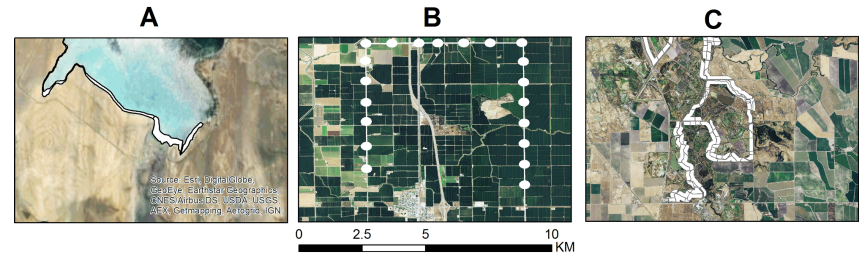

collected data on the habitat conditions at each sampling unit. Observers visually estimated the percent of the sampling unit that was flooded, vegetated, and bare ground, as well as the average vegetation height and up to two dominant cover types from a defined list.

Sampling variance: We recorded data on weather conditions during the survey and the proportion of the sampling unit that was able to be surveyed without visual obstruction, a necessary condition for unbiased shorebird counts, to account for sampling variance. Although there was no maximum time limit for surveying an individual sampling unit, the protocol instructed surveyors to end the survey after all birds in the sampling unit were recorded and to complete the survey as rapidly as possible to limit bird movement. The minimum survey time was two minutes to ensure that if shorebirds were present in the unit they would be detected, even if upon an initial observation there appeared to be no birds present.

These complexes provided access to $>20,000$ ha of regularly flooded wetland habitat, which was well distributed across the interior region. We prioritized wetland complexes that met one or more of the following criteria: (1) had at least 170 ha of flooded wetlands, (2) had $>10 \%$ of the total area as flooded wetlands, and (3) had an existing monitoring program. There were 17 complexes in our sampling frame that met at least two of the requirements. We also surveyed large tracts of privately owned managed wetlands in the Grassland Ecological Area of the Central Valley.

Along survey transects of managed wetlands, sampling units (units) were defined by the boundaries of the wetland management unit, the survey route, and a parallel line $161 \mathrm{~m}$ away from the road into the wetland (Fig. 2C). The maximum survey distance of $161 \mathrm{~m}$ ( 0.1 miles) for wetlands and flooded agriculture was determined from pilot surveys to evaluate the effect of distance on the probability of detection in interior habitats (M. Reiter, unpublished data).

\section{Site conditions}

Process variance: To account for differences in shorebird counts likely driven by ecological mechanisms, i.e., process variance, we
Shorebirds, particularly small Calidrid sandpipers, often occur in large groups of mixed species making it difficult to distinguish among species in the field and thus counts of mixed-species flocks are sometimes recorded instead of individual species counts. Mixed-species flocks generate error for species-specific totals and are a form of sampling variance that can lead to biased assessments, if the distribution of the collection of mixed-species flock data is not random. We assessed spatial variability in the proportion of counts that were mixed flocks in our data using a generalized linear mixed model with random effects of site and sampling unit within site (Zuur et al. 2009). We then applied a step-wise correction factor to partition small Calidrid sandpiper mixed-flocks to individual species totals after determining the ratio of those species present during that survey or averaged from past surveys of the sampling unit. Because some small species have specific habitat requirements, we used the ratio of identified species in the specific sampling unit from other years as likely the best representation of species composition when no data on those individual species were recorded during a survey of the unit in a given year. If species were not detected during the other years in the sampling unit, we used the ratios for species calculated for the 
whole site from the year of the survey or the average from other years at the site, if those individual species were not recorded in any other unit at the site in a specific year. Allocated species counts were then added to pure counts of each of the respective species. For example, if we observed 50 Dunlin, 50 Western Sandpipers, and 50 Least Sandpipers (Calidris minutilla) and then a mixed flock of 30 small Calidrid sandpipers, our total corrected count would be 60 Dunlin, 60 Western Sandpipers, and 60 Least Sandpipers. We used the corrected species estimates to calculate the proportion of the biogeographic population we counted each year.

\section{Data analysis}

We used three survey years of data (2013-2014; 2014-2015; 20152016) to evaluate (1) sources of variance in our field protocols, (2) variation in threats in our cross-sectional survey design, (3) shorebird habitat associations, and (4) two hypothesized threats. We used summary statistics (mean, standard deviation) of observed site conditions and other metrics recorded during the survey (e.g., start and end times) to characterize the sources of sampling and process variance as the result of our protocols. Across other analyses we used generalized linear mixed effects models (GLMM; Gelmen and Hill 2007, Zuur et al. 2009) so that we could understand the relative variation in bird abundance, habitat, and threats across sampling units and sites but also to control for correlation in shorebird abundance between sites and sampling units when using models for assessing shorebird associations with habitat and threats. The general hierarchical model form was:

$$
C_{i j k l} \sim \exp \left[\sum \beta_{i j k l} * x_{i j k l}+\sum \gamma_{i j k l}\right]
$$

Where $C_{i j k l}$ is the response variable in sampling unit $i$ on route $j$ (interior only) in site $k$ and in year $l ; \Sigma \beta_{i j k l} * X_{i j k l}$ is the set of fixedeffect parameters multiplied by covariate values, e.g., habitat types, evaluated in the model; and $\Sigma \gamma_{i j k l}$ is the set of random effects, e.g., site or sampling unit, and correlation structures in the model. We included the size of the sampling unit (natural log of ha) as a fixed effect in each model to account for variation in area surveyed, as well as a random effects of sampling units nested within the site (Gelman and Hill 2007).

We fit all models using maximum likelihood estimation in the glmmTMB package (Brooks et al. 2017) in R v. 3.3.3 (C) 2017 The $\mathrm{R}$ Foundation for Statistical Computing). We evaluated residual plots of all models for evidence of lack of fit (Zuur et al. 2009) and tested residuals for evidence of overdispersion (Cochran 1977) and spatial autocorrelation (Moran 1950).

\section{Design assessment}

To understand the influence of variable sampling effort and likely other factors (habitat, site selection) across regions, we compared the precision of shorebird abundance estimates across our regions by fitting a GLMM of shorebird abundance as a function of region and calculating the relative standard error of the estimated mean abundance for each region (standard error of the estimate / mean; RSE). We also compared the sampled focal cover types to the availability of those cover types to highlight variability in habitat surveyed across regions and thus the ability of our survey to broadly quantify habitat associations. This comparison also provided an indication of the selection probability across cover types in the different regions. Last, to assess how well our crosssectional sampling design was gathering data to understand the impact of the hypothesized threats, we quantified the within- and among-site variation in threats where we had field- (bird abundance, avian predators) and/or GIS- (human disturbance) derived data using an intercept-only mixed-effects models with random effects for sampling unit and site, as well as an overdispersion parameter. When considering the amount of urbanization (proportion of area classified as urban) as an indicator of potential disturbance, we evaluated multiple spatial scales around a sample unit (1-, 5-, and $10-\mathrm{km})$ because generally we did not have sampling units dominated by urban landscapes. For these GLMMs decomposing variance among units and sites, we assumed a negative binomial distribution of counts of all shorebirds and predators and used a log-link, while for the amount of urbanization (index of human disturbance) as the response we assumed a normal distribution. The parameter estimates for the random effects were then used to compare among sampling unit and among site variance. Note that these analyses of variability in threats considered predator abundance and urbanization as response variables, in contrast to subsequent analyses where they were included as explanatory variables to evaluate their effect on shorebird abundance.

\section{Habitat associations}

We assessed how coastal shorebird abundance (all species from Table 1 combined) varied as a function of the amount of five focal coastal cover types derived from GIS data. We also modeled associations of shorebirds with the habitat conditions recorded during the field survey including the proportion of flooded, bare, and vegetated cover within a sampling unit. We considered five separate models: one for each covariate (percent flooded, bare, or vegetated) and then two additional models that included a quadratic term for percent flooded and percent bare. We fit quadratic models based on the hypothesis that shorebirds, which generally feed near shorelines, would seek an optimal balance between flooded and bare habitats (Reiter et al. 2015). Because measures of percent bare and percent flooded were correlated (correlation coefficient $=-0.69$ ), we did not include them in the same model. However, we hypothesized that shorebirds would be positively related to these two conditions because shorebirds are often found foraging in a mix of flooded and bare habitats, so we evaluated both variables but in separate models. We ranked models using Akaike's Information Criterion (AIC; Burnham and Anderson 2002) to understand the relative influence of different habitat conditions and evaluated their coefficient estimates and $95 \%$ confidence intervals $(\mathrm{CI})$ to characterize their direction of association with bird abundance.

\section{Hypothesis evaluation}

We used field based estimates of avian predators (predators/ha) and GIS derived data on potential human disturbance (proportion urban land cover near the sampling unit) in combination with shorebird counts to evaluate hypotheses that increased predators and increased disturbance would result in decreased shorebird abundance (Table 4). We considered all avian predators per ha and the total of Peregrine Falcons (Falco peregrinus) counted per ha, separately, as predictor variables in models of overall shorebird abundance. When evaluating the associations between bird abundance and the amount of 
urbanization (proportion of area classified as urban) within multiple spatial scales around a sample unit (1-, 5-, and 10-km), we assumed a negative binomial distribution of shorebird counts and used a log-link in our GLMM.

\section{RESULTS}

\section{General summary}

Between 2011 and 2016, we initiated the Project in 11 countries with the help of more than 40 partner organizations and hundreds of volunteers. On average, across three survey years (2013-2016), we visited 1410 sampling units per year among 84 sites embedded in the 3 regions (Tables 2 and 3). We conducted surveys at $57 \%$ of identified sites with $>500$ shorebirds counted in any historical survey. The North Temperate (coastal and interior) and Neotropical regions had a higher proportion of sites surveyed than the South Temperate region. Sampling units along interior road transects were aggregated to the transect level to achieve similar spatial extent to coastal sampling units. Overall there were fewer equivalent sampling units surveyed in our interior sites ( $n$ $=110)$ compared to the coast $(n=1319)$. However, interior surveys accounted for $33 \%$ of the total area surveyed each year $(31,248$ ha) with the remaining $67 \%$ in coastal sampling units $(64,295 \mathrm{ha})$.

We recorded similar total numbers of shorebirds each year, however, counts varied somewhat because of variable survey effort: $1,033,169$ shorebirds on 98,170 ha in 2013-2014; 960,163 shorebirds on 88,512 ha in 2014-2015; and 1,097,927 on 88,892 ha in 2015-2016. After initial surveys in winter of 2013-2014, there was more limited coverage in Central America in 2014-2015 but then increased effort with all countries returning for 20152016 along with the addition of Costa Rica. We counted at least one individual representing 44 species of shorebirds and encountered six types of mixed-species flocks (Table 1). Overall, total species richness was higher at coastal sites (40 species) compared to interior sites (19 species).

In all, 34\% of total small sandpipers (Calidris spp.) were recorded as mixed-species flocks. After applying our approach for partitioning mixed-species flocks to species, estimates of total abundance for Sanderling (Calidris alba), Dunlin, Semipalmated Sandpiper (C. pusilla), Least Sandpiper, and Western Sandpiper increased by $77 \%, 6 \%, 37 \%, 93 \%$, and $11 \%$, respectively (Table 1 ). The total number of less abundant but common species (Sanderling and Least Sandpiper) in mixed flocks, proportionally, increased the most when data were collected as mixed flocks. Mixed-species flocks of Long-billed (Limnodromus scolopaceus) and Short-billed Dowitchers (L. griseus) and Lesser (Tringa flavipes) and Greater Yellowlegs (T. melanoleuca) were also recorded. Because of the challenge of differentiating Long-billed and Short-billed Dowitchers in the field, $84 \%$ of Dowitchers were not identified to species. However for Yellowlegs spp., only $4 \%$ of observations could not be identified as Greater or Lesser Yellowlegs (281 birds in total).

Using the average total annual count (or corrected count) of each species and estimates of species population sizes (Andres et al. 2012), we identified 14 species for which we recorded $>5 \%$ of their estimated biogeographic population each year (Table 1). Of those, five species had $>20 \%$ of their biogeographic population being recorded annually. Our primary focal species from the initial project development, Dunlin and Western Sandpiper, were the most abundant species observed ( $~ 500,000$ and 1 million counted, respectively), however we only recorded one individual of Mountain Plover (Charadrius montanus), Bar-tailed Godwit (Limosa lapponica), and Wandering Tattler (Tringa incana) between 2013 and 2016.

Across the 11 countries, the largest concentrations occurred at known important places for shorebirds in the Pacific Americas Flyway, including San Francisco Bay (USA), the Upper Bay of Panama (Panama), and Ensenada de Pabellones (Mexico) with $24 \%, 23 \%$, and $11 \%$ of the average annual count of all shorebirds in these three sites, respectively. Abundance at these three critical sites above was largely driven by the Calidrid sandpipers: primarily, Western Sandpiper, Dunlin, Least Sandpiper, and Semipalmated Sandpiper. Humboldt Bay (USA), Bahia Santa Maria (Mexico), and Laguna Ojo de Liebre (Mexico) were also known sites of importance where $>4 \%$ of the birds were counted annually (Table 5). We also identified sites that were not known to be important from any previous surveys, but were particularly significant for certain species. For example, newly developed surveys for Delta del Rio Estero Real in Nicaragua identified $\sim 20 \%$ of the known population of Wilson's Plovers (Charadrius wilsonia) and we observed $4 \%$ of the total shorebirds counted by the Project, on average, across the broader Gulf of Fonseca, a coastline shared by El Salvador, Honduras, and Nicaragua (Tables 1 and 5).

When comparing model-based estimates of all shorebird abundance across regions, the largest relative standard error (RSE) of density estimates (SE/mean) was in the South Temperate Region (1.94) while the smallest RSE was in the North Temperate Region (0.39) The RSE in the Neotropical Region (0.59) was just a bit larger that the North Temperate Region. The pattern of RSE across regions follows sampling effort differences with the South Temperate having the lowest survey effort in this dataset (Table 3).

\section{Protocol and sources of variance}

\section{Process variance}

Habitat conditions recorded in the field varied, largely reflecting differences in cover types. Field observations indicated that we surveyed across a gradient of potential cover types from shorebird habitat ( $85 \%$; e.g., intertidal flat, tidal salt marsh, salt pond, beach) to nonhabitat ( $15 \%$; e.g., developed, forest). The average proportion of the sampling unit that was flooded, bare, or vegetated was $0.50(\mathrm{SD}=0.34), 0.31(\mathrm{SD}=0.32)$, and $0.17(\mathrm{SD}$ $=0.23$ ), respectively. When we modeled the variance associated with individual site conditions, we found that the proportion bare varied equally among sites $(0.62, \mathrm{SD}=0.79)$ and among units within sites $(0.60, \mathrm{SD}=0.78)$. However, the proportion flooded had lower among site variance $(0.29, \mathrm{SD}=0.54)$ than among unit within site variance $(0.59, \mathrm{SD}=0.77)$, and the proportion vegetated had slightly higher among site variance $(1.05, \mathrm{SD}=$ $1.03)$ than among unit within site variance $(0.85, \mathrm{SD}=0.92)$.

\section{Sampling variance}

There was variation in the size of sampling units $(<1->5000$ ha) though variance in unit size was similar among sites (1.38 ha, $\mathrm{SD}=1.18)$ as well as among units within sites $(1.27 \mathrm{ha}, \mathrm{SD}=$ 1.13). Survey duration also varied among sites $(0.30 \mathrm{~h}, \mathrm{SD}=0.55)$ and among sampling units within sites $(0.19 \mathrm{~h}, \mathrm{SD}=0.44)$. As 
expected, there was a positive $($ Pearson's correlation coefficient $=$ $0.41 ; 95 \% \mathrm{CI}: 0.39,0.44)$ significant correlation $(t=26.11, d f=$ $3256, \mathrm{P}<0.001)$ between unit size and survey duration. Consequently, we used only the natural logarithm of the area of a sampling unit as a covariate in our models to control for survey effort.

The average percentage of the sampling unit that was visible was high though did vary $($ mean $=91 \%, \mathrm{SD}=17)$. The percent visible area was higher in coastal areas (mean $=96 \%, \mathrm{SD}=16.5$ ) compared to interior units (mean $=85 \%, \mathrm{SD}=16.2)$. This difference largely highlights the vegetation in the interior freshwater wetland habitats of the Central Valley of California that can grow to obstruct visibility, but as well changes in landcover on private lands surveyed in the interior. As the result of this difference between interior and coastal area visibility, we analyzed habitat associations of coastal shorebirds only so that unaccounted for subregional differences in visibility would not bias this analysis. We assumed that variation in bird counts as the result of visibility in coastal areas was random with respect to cover types.

The probability of occurrence of mixed flocks in the data varied more among sites than among units within sites suggesting that for some sites there was a higher likelihood of mixed flocks than for others. This spatial variation in the probability of mixed flocks indicated that using corrected values for the total of Calidris species is needed when comparing species-level abundances.

\section{Design assessment}

As we had hoped, we found among site and among unit within site variation in shorebird abundance, habitat, and some indices to hypothesized threats. Shorebird abundance in sampling units varied both among sites (random effect of site $=4.2, \mathrm{SD}=2.0$ ) and among sampling units within sites (random effect of units within site $=2.9, \mathrm{SD}=1.7$ ). Habitat sampled varied among regions, sites, and sampling units. In the North Temperate coastal region, our sampling units were dominated by intertidal mudflats $(60 \%)$ then salt marsh $(26 \%)$ followed by salt ponds (aquaculture, $11 \%)$ and beach ( $3 \%$; Fig. 3$)$. In the interior portion of the North Temperate region, freshwater wetlands (55\%), saline lakes $(26 \%)$, rice $(9 \%)$, and other suitable agriculture $(9 \%)$ composed the primary habitat types (Fig. 3). Overall, we surveyed tidal mudflats and aquaculture equal to their availability, slightly oversampled salt marsh, and sampled beaches less than their availability. In the interior subregion of the North Temperate region, we undersampled flooded agriculture relative to its availability but oversampled wetlands and saline lakes. Both the Neotropical and South Temperate regions were completely coastal. Mangrove forests $(15 \%)$ and aquaculture ponds $(13 \%)$ were more abundant in the Neotropical region, relative to the South Temperate (Fig. 3). Although aquaculture was surveyed in proportion to its availability, mangroves were undersampled and mudflats were oversampled. In the South Temperate region, mangroves did not occur and beaches composed a relatively larger fraction of the habitat in sampling units $(29 \%)$ compared to other regions. In the South Temperate region, beaches were still undersampled relative to their availability as well as aquaculture, whereas mudflats and tidal marsh were oversampled.
Fig. 3. Summary of the composition of focal cover types surveyed $(\mathrm{A}, \mathrm{C})$ compared to the composition available $(\mathrm{B}, \mathrm{D})$ in all coastal regions $(A, B)$ and interior sites of the North Temperate region (C, D) as part of the Migratory Shorebird Project along the Pacific Coast of the Americas 2013-2016.
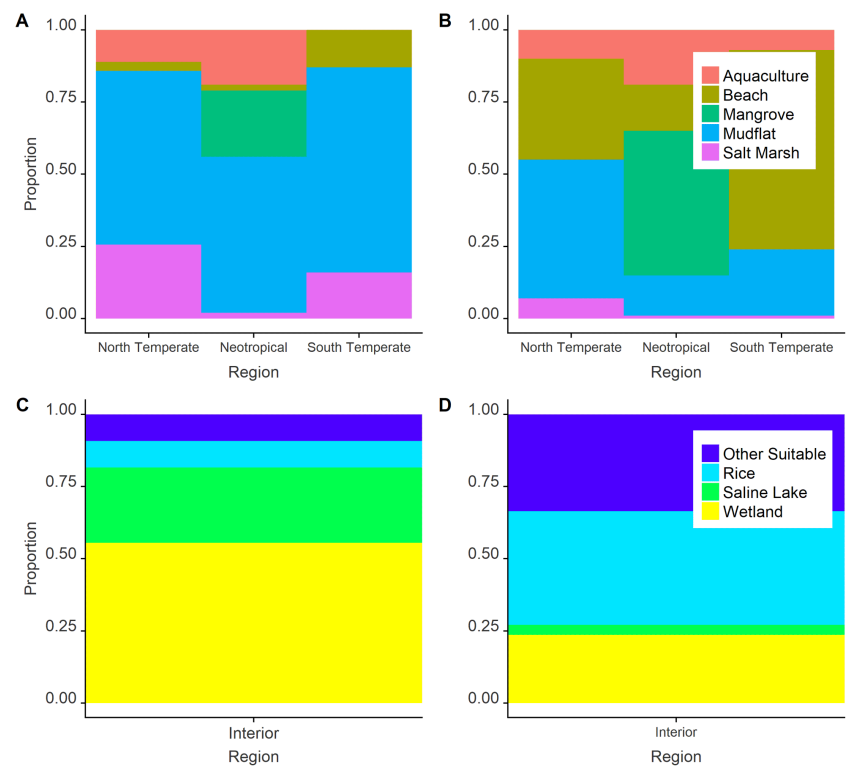

The relative abundance of Peregrine Falcons, the primary predator of shorebirds across much of the study area, was variable across units $($ mean $=0.003$ birds $/$ ha; $S D=0.031)$ but varied similarly both across sites (random effect of site $=1.05$; $\mathrm{SD}=$ 1.03 ) and among units within sites (random effect of units within site $=0.75 ; \mathrm{SD}=0.86$ ). Overall, $47 \%$ and $35 \%$ of the residual variance in Peregrine Falcon abundance after accounting for the size of the sampling unit could be attributed to variance among sites and among units within sites, respectively. Overall, the mean and variance of the proportion of urbanization surrounding units (our index to disturbance) in our sample was nearly the same at all spatial scales $(1-\mathrm{km}$ : mean $=0.48, \mathrm{SD}=0.50 ; 5-\mathrm{km}$ : mean $=$ $0.49, \mathrm{SD}=0.50 ; 10-\mathrm{km}$ : mean $=0.49 ; \mathrm{SD}=0.50)$. Residual among unit variance in the amount of urbanization was low compared to among site variance within 1-, 5-, and 10-km buffers. Among site variance accounted for $>99 \%$ of the residual variance in urbanization in sampled units at all three buffer scales. This limited within-site variability in urbanization suggests that within-site assessments of the effect of urbanization on shorebirds may not be as informative as comparing among units across all sites.

\section{Habitat associations}

The amount of intertidal mudflat had a significant positive association with total shorebird abundance $(\beta=0.13 ; 95 \% \mathrm{CI}$ : $0.04,0.22)$, when assessing all shorebird species combined in coastal habitats, as well as the amount of beach $(\beta=0.23 ; 95 \%$ CI: $0.02,0.44)$, and aquaculture, i.e., shrimp and salt production ponds $(\beta=0.17 ; 95 \% \mathrm{CI}$ : $0.03,0.30)$. However mangroves $(\beta$ $=-0.02 ; 95 \%$ CI: $-0.39,0.35)$ and salt marsh $(\beta=0.08 ; 95 \%$ CI: $-0.01,0.18$ ) had uncertain associations with shorebirds as both had $95 \%$ confidence intervals that overlapped zero. 
For the five models using field collected site condition data to characterize habitat associations, the nonlinear (quadratic) bare ground model fit the best based on AIC and suggested that shorebirds were abundant in habitats with moderate amounts of bare ground (Table 6, Fig. 4). Other models had relatively larger AIC values. However, shorebird density was also nonlinearly associated with the proportion flooded area and was negatively associated with the proportion of the sampling unit that was vegetated (Fig. 4); 95\% confidence intervals of parameter estimates for these models did not overlap zero (Table 6).

Table 6. Summary of generalized linear mixed models fit to all 44 shorebird species to assess the influence of site conditions (percent flooded, bare, and vegetated). Models are ranked from lowest to highest Delta AIC (Akaike's Information Criterion). Delta AIC is the difference between each model AIC and the model with the lowest AIC. $95 \% \mathrm{CI}=95 \%$ Confidence Intervals of parameter estimates. We considered $95 \%$ CI that did not overlap zero to be significant.

\begin{tabular}{lccc}
\hline \hline Model & $\begin{array}{c}\text { Delta } \\
\text { AIC }\end{array}$ & Parameter & Estimate $(95 \% \mathrm{CI})$ \\
\hline Quadratic & 0 & Bare & $4.46(3.31,5.62)$ \\
Percent Bare & & Bare $^{2}$ & $-3.98(-5.19,-2.78)$ \\
& & Area & $0.63(0.65,0.90)$ \\
Quadratic & \multirow{2}{*}{30} & Flood & $3.03(1.86,4.21)$ \\
Percent Flooded & & Flood & $-3.30(-4.46,-2.16)$ \\
& & Area & $0.63(0.53,0.73)$ \\
Percent Vegetated & \multirow{2}{*}{38} & Vegetated & $-1.34(-1.87,-0.81)$ \\
& & Area & $0.66(0.57,0.76)$ \\
Percent Bare & \multirow{2}{*}{40} & Bare & $0.86(0.49,1.22)$ \\
& & Area & $0.64(0.54,0.74)$ \\
Percent Flooded & \multirow{2}{*}{60} & Flood & $-0.22(-0.55,0.11)$ \\
& & Area & $0.64(0.54,0.74)$ \\
\hline
\end{tabular}

\section{Hypothesis evaluation}

We articulated seven hypotheses and 13 associated predictions about how five main threats would impact shorebirds and thus what we would expect in the data. We identified both field-based and remote sensing-based approaches for characterizing potential threats that could be used in analyses (Table 5; Appendix 1) and tested these approaches in initial evaluations of two hypotheses from the hypothesis framework. We found that higher shorebird density was significantly associated with more Peregrine Falcons $(\beta=4.44 ; 95 \% \mathrm{CI}=0.83,8.05)$ and with overall avian predator abundance $(\beta=1.68 ; 95 \% \mathrm{CI}=0.21,3.16)$. However, shorebird density was not significantly associated with the amount of urbanization, our index to human disturbance from GIS data, at the 1-, 5- or 10-km buffer scale. Overall, analysis of residuals from all models suggested good model fit and no significant $(\mathrm{P}>0.05)$ residual spatial correlation or overdispersion.

\section{DISCUSSION}

The Migratory Shorebird Project is a hypothesis-driven research and monitoring framework for shorebirds that will quickly advance the pace and scale of their conservation and management. We used historic data on shorebird distributions and habitat along with a set of hypotheses to guide the semistructured design and collection of data from across the nonbreeding range of many migratory shorebirds on the Pacific
Coast of the Americas to be able to understand habitat associations and threats to shorebirds and over the longer term trends. We quantified the importance of both intertidal mudflats and beaches as well as aquaculture for shorebirds in these coastal landscapes. Standardized protocols, a workforce of biologists and trained volunteers, centralized data management, and a multinational network make MSP an example of building sustainable capacity to gather the necessary information to guide and measure the success of conservation and management actions. With the Project poised to continue, we are well positioned to use this framework to help solve some of the biggest challenges facing migratory shorebirds and the wetland habitats they rely on.

Fig. 4. Estimated density of shorebirds (birds/ha) and 95\% confidence interval bands from mixed-effects models of the associations of shorebirds with site conditions: (A) proportion bare ground; (B) proportion flooded; and (C) proportion vegetated.
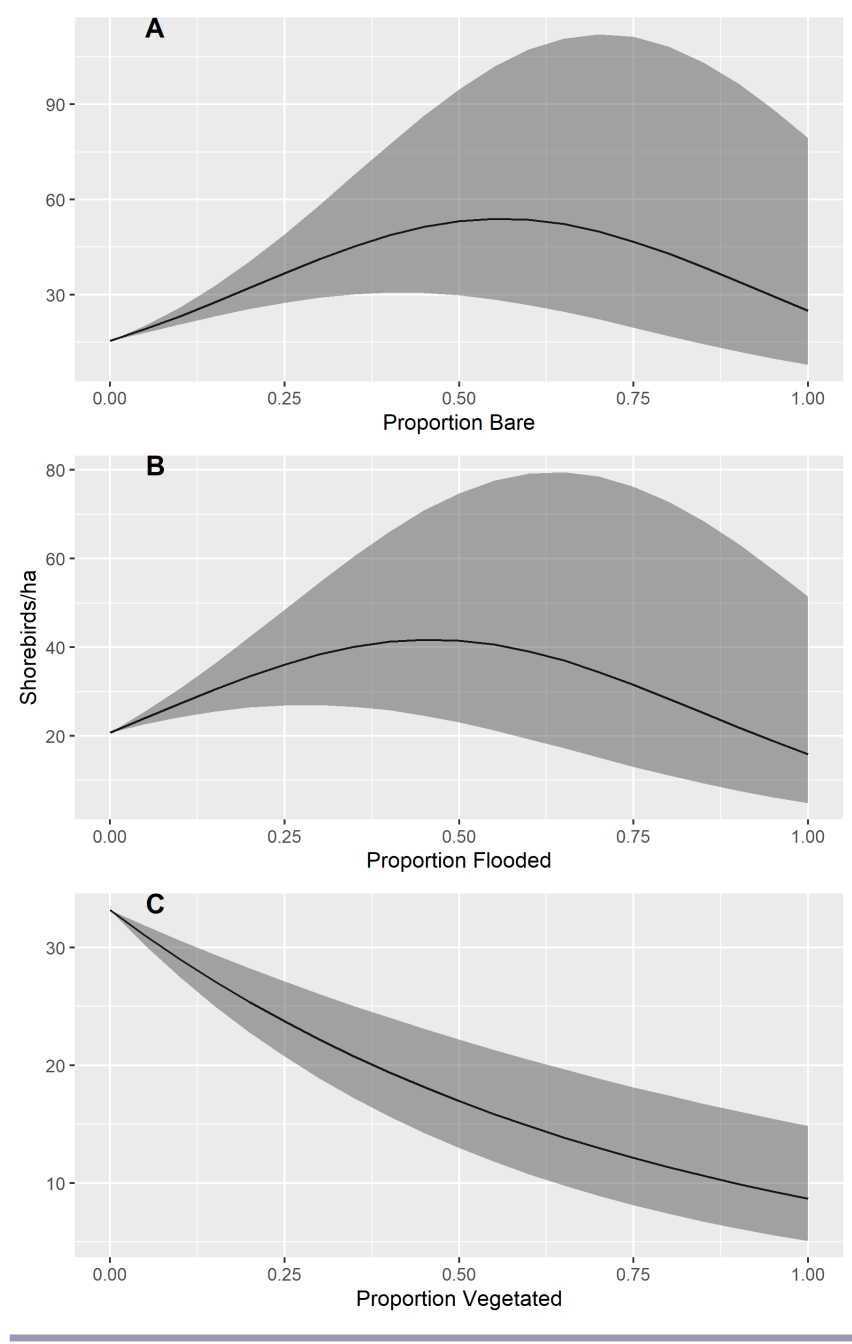

Project data indicated that, each year, we are collecting information on a large fraction of the population for many shorebird species, and particularly our focal species of Western Sandpiper and Dunlin. This suggests that the Project will provide 
sufficient data after additional years of surveys to improve trend estimates for many shorebird populations at sites across the Pacific Coast of the Americas (Andres et al. 2012, Senner et al. 2016). As more data are collected, the uncertainty around estimates will decline, and we will be increasingly able to control for sources of variation such as habitat or landscape context to further reduce uncertainty (Williams et al. 2002). Precision of the regional density estimate for all shorebirds was lowest in the South Temperate region. In response, the Project is now collaborating with other existing shorebird monitoring programs to increase sampling intensity (e.g., Peru and Chile Shorebird Atlases; Senner and Angulo Pratolongo 2014, Garcia Walther et al. 2017), and subsequently reduce uncertainty around density estimates in that region. We also recognize that the abundance of data derived from mixed-species flocks contributes additional uncertainty to species-specific estimates presented here.

Understanding the ecological mechanisms that establish highly productive coastal areas used by shorebirds will be important for their conservation. Similar to other studies, densities of shorebirds in coastal areas was strongly associated with the amount of intertidal mudflats (Butler et al. 1997), beaches (Neuman et al. 2008), and salt and shrimp operations (Yasué and Deardon 2009). The low use of mangroves may reflect the timing of surveys, which did not occur at high tide when shorebirds may roost in mangroves (Zharikov and Milton 2009, JohnstonGonzález and Abril 2018), as well as the fact that overall there were lower shorebird densities with higher vegetative cover indicating that shorebirds likely do not forage in mangroves. Higher vegetative cover may be correlated with increased risk of predation (Pomeroy 2006, Pomeroy et al. 2006). Positive associations with salt and shrimp ponds highlight the use of those habitats, where they are available (Navedo et al. 2015), and the need to seek collaboration with producers to better understand what wildlife habitat is available on these working lands (Senner et al. 2016).

Our analyses suggest that moderate amounts of bare mud or ground is associated with greater densities of shorebirds. A similar nonlinear pattern was observed for the amount of area that was flooded. We attribute these nonlinear relationships to the fact that shorebirds frequently forage along the edge of water or in mixed substrates and thus there may be a threshold beyond which more bare ground or flooded area has reduced benefit (Burger et al. 1977). Understanding this relationship is important for managers that manually flood wetlands or agricultural lands because ultimately too much water or water that is too deep (Strum et al. 2013) may be a deterrent for migratory shorebirds. Furthermore, as coastal regions are threatened by sea-level rise, sustaining intertidal mudflats so that there is a consistently available mix of bare and flooded habitat for shorebirds is essential when developing adaptation strategies.

The estimated variance in bird abundance, both within and among sites, and indices to human disturbance and predators highlights the cross-sectional sampling design of the Project. Our initial analyses explored the associations of potential predators and disturbance on shorebird density. Interestingly, contrary to our predictions, higher densities of shorebirds were associated with higher predator abundance. This is likely caused by two key factors. First, the relative abundance of shorebirds across our sites did not vary greatly year to year suggesting that predators can likely discover and then move to the locations of large concentrations of shorebirds. Second, shorebirds likely concentrate in large groups to reduce the risk of predation, which could result in higher densities of shorebirds occurring in areas with high predation risk (Barbosa 1997). However, another explanation can be found in the hypothesis framework where we predict, based on other studies (e.g., Ydenberg et al. 2017), that trends in predator abundance will determine trends in shorebird abundance and those may vary depending on the safety of the site (Pomeroy et al. 2008; Table 4, Appendix 1). Ultimately, our initial analyses of only three years of data may not be sufficient to understand broad-scale spatial patterns in this predator-prey relationship that evolve over decadal time periods (Ydenberg et al. 2017).

We found no significant association between shorebird density and our index of disturbance based on the amount of human development. We had predicted a negative association between birds and measures of disturbance (Table 4, Appendix 1). The lack of association may be attributed to using too coarse of an index of potential disturbance; we assumed shorebird habitats near developments were more disturbed by human activities than habitats away from developments. This may not be a good assumption and land cover data may not reflect a behavioral-based process such as disturbance, which has been shown to negatively affect shorebird abundance in other studies (Pfister et al. 1992). The effects of disturbance may also be hard to detect using survey data because site fidelity may mask the real effects on body condition and survival (Gibson et al. 2018). However, species with lower wintering site fidelity may reveal disturbance impacts through count data. To gather more precise data on human disturbance impacts, we developed and deployed a field protocol in 2016 to characterize potential disturbance factors, e.g., dogs or humans, at sampling units across the Project as part of ongoing annual ground surveys.

There are challenges associated with collecting data using a crosssectional design, particularly when seeking to eventually analyze temporal trends. The cross-sectional approach induces variability in the count data to allow for hypotheses to be evaluated. However, this variation in bird abundance within and across sites can inflate uncertainty in annual density estimates. We removed sampling units $<1$ ha and $>1000$ ha, and used area as a covariate in all models, which reduced the variance in estimates. Trend models will have to consider filtering observations based on suitable habitat to reduce uncertainty in annual abundance estimates thus increasing power to detect trends over time (Bart et al. 2005). The trade-off between suitable variation in bird abundance to assess specific hypotheses and lower levels of variation that can be better for estimating trend needs to be considered when developing a monitoring strategy for multiple objectives.

Overall, our allocation of sampling effort by habitat across the Project was not always proportional to availability but reflected both the relative use by shorebirds and availability of the habitat on the landscape. Overall, we sampled the highest proportion of some habitats that received the most use, tidal mudflats and aquaculture, but generally undersampled the important beach habitat. Although beaches are important to a certain subset of shorebirds, our design put limited emphasis on sampling beaches 
because they are not thought to be critical foraging habitat for our primary focal species of Western Sandpiper and Dunlin. Over the last two years, we have increased our sampling effort along beaches in the North Temperate region to better capture use of that habitat.

Finally, although we made great efforts to use existing data on habitat, threats, and shorebird abundance, and randomization at the sampling unit level, to guide our site and sampling unit selection, we faced many limitations to implementing a fully randomized design throughout the large landscape. Implementation of a survey of this extent requires a methodology that is efficiently repeatable. Consequently many of sampling units are located along roads or shorelines that have public access. Although we recognize the potential bias in counts toward accessible areas, we have no reason, based on data we have collected to date and from the literature, to think that shorebirds are biased away from roads or shorelines. Also given the lack of ability to implement a fully randomized design, caution is needed when trying to extend inference from our selection of sites to the broader population. Nonetheless, we feel that our design is suitably representative of a large fraction of the sampling frame. Also because we do not survey a large number of sites with $<500$ shorebirds and not all sites with $>500$ shorebirds, efforts should be made over time to include new sites, at least occasionally, to guard against possible bias, particularly sample and frame bias, related to our current survey design. Last, more effort is needed to derive a spatial inventory of all indices of threats identified in our hypothesis framework to ensure our survey sites and units represent variation across all potentially measured threat variables and thus enable additional assessments of the impact of the different threats on shorebirds.

\section{CONCLUSION}

The Migratory Shorebird Project is a carefully designed research and monitoring framework that provides essential data on migratory shorebirds for the Pacific Coast of the Americas. The Project network serves as a conduit to bring data and research to existing shorebird conservation efforts. Data collected as part of the Project informs the conservation of important shorebird habitat at Western Hemisphere Shorebird Reserve Network (WHSRN) sites and were essential for designating the first WHSRN site in Nicaragua: Delta del Rio Estero Real (https:// www.whsrn.org/delta-del-estero-real). Through our engagement across a broad range of researchers with diverse backgrounds, we are increasing capacity to answer questions that are relevant to multiple stakeholders at individual sites and across the nonbreeding range of wetland-dependent shorebird populations.

It is challenging to ask questions about wide-ranging shorebird populations and the impact of threats and climate change at multiple scales using monitoring data without broad-scale coordination and strategic design. Migratory Shorebird Project data collected with our international network can be used to generate an initial set of species distribution models, current threat evaluations, and subsequently spatially explicit assessments of the vulnerability of shorebirds to sea-level rise both within a specific estuary and across our set of sites along the Pacific Coast under different climate change scenarios (Iwamura et al. 2013). These vulnerability assessments can guide conservation prioritization (Moilanen 2007) that considers both current threats and future conditions when making conservation plans today (Conroy et al. 2011, Veloz et al. 2013) ensuring they are successful for generations despite an uncertain future.

Responses to this article can be read online at: http://www.ace-eco.org/issues/responses.php/1620

\section{Acknowledgments:}

The Migratory Shorebird Project would not have been possible without the dedication of hundreds of volunteers and partner biologists each year representing nearly 50 organizations and agencies. Specifically we thank Point Blue Conservation Science, D. Moody, M. Fitzgibbon, L. Salas, T. Gardali, D. Shuford, L. Stenzel, G. Page, Terra Peninsular, Exportadora de Sal, S.A., CONANP, Prescott College, F. Romero, G. Brabata, D. Molina, E. Muñoz-Salas, E. Amador-Silva, G. Fernandez, D. Galindo, L. Alfaro, J. Vargas, A. Heredia, M. Cruz-López, S. Gómez del Angel, E. Soto, A. Hanuksela, M. González, S. González, Mark Colwell, Birds Canada, Pacific WildLife Foundation, K. Barry, K. Devitt, Environment and Climate Change Canada - Canadian Wildlife Service, D. Hope, U.S. Geological Survey, J. Takekawa, U.S. Forest Service, G. Butcher, R. Alvarado, C. Howell, E. Cooper, C. Carrothers, $W$. Owen, C. Lively, Environment for the Americas, $U$. S. Fish and Wildlife Service, B. Andres, V. Loverti, R. Lanctot, M. Bailey, C. Sundstrum, P. Meyers, S. Thomas, B. Collins, O. Richmond, C. Beardmore, B. Treiterer, M. Freis, C. Strong, T. Anderson, M. Wolder, J. Isola, R. Doster, B. Bridgeland, K. Gilligan, Ecostudies Institute, G. Slater, Pilchuk Audubon, Whidbey Audubon, North Cascades Audubon, Skagit Audubon, San Diego Audubon, U.S. Navy, M. Ruane, T. Shephard, Manomet Center for Conservation Sciences, National Audubon Society, S. Fork, Sea and Sage Audubon, Audubon California, M. Iglecia, A. Jones, Bolsa Chica Conservancy, California Department of Fish and Wildlife, L. Sparks, D. Feliz, D. VanBaren, L. Cockrell, Grassland Water District, Audubon Canyon Ranch, E. Condensa, San Francisco Bay Bird Observatory, Washington Department of Fish and Wildlife, $R$. Milner, K. Molina, Salvanatura, V. Galán, A. Moisés, Asociación de Ornitólogos de Honduras, J. van Dort, R. Juárez, Quetzalli, S. Morales, E. Reyes, O. Jarquín, Unión de Ornitólogos de Costa Rica, L. Sandoval, I. Gutierrez, Panama Audubon, R. Miro, K. Kauffman, M. Caballero, Y. Díaz, S. Carty, Asociación Calidris, F. Castillo, D. Estupiñán, Y. Cifuentes, Sanquianga National Park staff, Consejo Comunitario Esfuerzo Pescador, C. Congolino, C. Castillo, W. Estupiñán, E. Anchico, Aves y Conservación, A. Agreda, D. del Pexo, Servicio Nacional de Áreas Protegidas por el Estado (SERNANP), Reserva Nacional de Paracas, Naturaleza y Cultura Internacional, Corbidi, F. Angulo, P. Saravia, F. Suarez, M. Alzamora, Red de Observadores de Aves de Chile, S. Montecino, H. Norambuena, I. Tejeda, and F. Medrano. We also recognize the generous funding contributions of the David and Lucile Packard Foundation, U.S. Forest Service International Programs, the Mennen Environmental Foundation, U.S. Fish and Wildlife Service, the Stephen D. Bechtel Jr. Foundation, and Environment and Climate Change Canada. We thank K. Hobson and five anonymous reviewers for comments that greatly improved this manuscript. This is a product of the Migratory Shorebird Project and Point Blue contribution number 2325. 


\section{LITERATURE CITED}

Andres, B. A., P. A. Smith, R. I. G. Morrison, C. L. Gratto-Trevor, S. C. Brown, and C. L. Gratto-Trevor. 2012. Population estimates of North American shorebirds. Wader Study Group Bulletin 119:178-194.

Barbosa, A. 1997. The effects of predation risk on scanning and flocking behavior in Dunlin. Journal of Field Ornithology 68:607-612.

Bart, J., B. Andres, S. Brown, G. Donaldson, B. Harrington, V. Johnston, S. Jones, G. Morrison, and S. Skagen. 2005. The program for regional and international shorebird monitoring (PRISM). General Technical Report PSW-GTR-191. U.S. Forest Service, Albany, California, USA.

Bart, J., S. Brown, B. Harrington, and R. I. G. Morrison. 2007. Survey trends of North American shorebirds: population declines or shifting distributions. Journal of Avian Biology 38:73-82. https://doi.org/10.1111/j.2007.0908-8857.03698.x

Brooks, M. E., K. Kristensen, K. J. van Benthem, A. Magnusson, C. W. Berg, A. Nielsen, H. J. Skaug, M. Maechler, and B. M. Bolker. 2017. glmmTMB balances speed and flexibility among packages for zero-inflated generalized linear mixed modeling. $R$ Journal 9:378-400. https://doi.org/10.32614/RJ-2017-066

Brown, S., C. Hickey, B. Harrington, and R. Gill, editors. 2001. United States shorebird conservation plan. Second edition. Manomet Center for Conservation Sciences, Manomet, Massachusetts, USA.

Burger, J., M. A. Howe, D. C. Hahn, and J. Chase. 1977. Effects of tide cycles on habitat selection and habitat partitioning by migrating shorebirds. Auk 94:743-758. https://doi.org/10.2307/4085271

Burnham, K. P., and D. R. Anderson. 2002. Model selection and multi-model inference: a practical information theoretic approach. Second edition. Springer, New York, New York, USA.

Butler, R. W., R. I. G. Morrison, F. S. Delgado, R. K. Ross, and G. E. J. Smith. 1997. Habitat associations of coastal birds in Panama. Colonial Waterbirds 20:518-524. https://doi.org/10.2307/1521602

Butler, R. W., R. C. Ydenberg, and D. B. Lank. 2003. Wader migration on the changing predator landscape. Wader Study Group Bulletin 100:130-133.

Cochran, W. G. 1977. Sampling techniques. Third edition. John Wiley and Sons, New York, New York, USA.

Conroy, M. J., M. C. Runge, J. D. Nichols, K. W. Stodola, and R. J. Cooper. 2011. Conservation in the face of climate change: the roles of alternative models, monitoring, and adaptation in confronting and reducing uncertainty. Biological Conservation 144:1204-1213. https://doi.org/10.1016/j.biocon.2010.10.019

Crewe, T., K. Barry, P. Davidson, and D. Lepage. 2012. Coastal waterbird population trends in the Strait of Georgia 1999-2011: results from the first 12 years of the British Columbia Coastal Waterbird Survey. British Columbia Birds 22:8-35.

Dickinson, J. L., B. Zuckerberg, and D. N. Bonter. 2010. Citizen science as an ecological research tool: challenges and benefits. Annual Review of Ecology, Evolution, and Systematics 41:149-172. https://doi.org/10.1146/annurev-ecolsys-102209-144636
Dybala, K. E., M. E. Reiter, C. M. Hickey, W. D. Shuford, K. M. Strum, and G. Yarris. 2017. A bioenergetics approach to setting conservation objectives for non-breeding shorebirds in California's Central Valley. San Francisco Estuary and Watershed Science 15(1):2. https://doi.org/10.15447/sfews.2017v15iss1art2

Elphick, C. S., and L. W. Oring. 1998. Winter management of Californian rice fields for waterbirds. Journal of Applied Ecology 35:95-108. https://doi.org/10.1046/j.1365-2664.1998.00274.x

Eusse, D., M. Cuervo, M. Garcia-Toro, Y. Hutado, and J. Estrada. 2017. Hábitats de aves playeras de la costa del Pacifico americano. Shapefile, 1:250.000, World Cylindrical Equal Area projection. Asociación para el estudio y conservación de las aves acuáticas en Colombia-Calidris, Cali, Colombia.

Fernández, G., J. B. Buchanan, R. E. Gill, Jr., R. Lanctot, and N. Warnock. 2010a. Conservation plan for Dunlin with breeding populations in North America (Calidris alpina arcticola, C. a. pacifica, and C. a. hudsonia). Version 1.1. Manomet Center for Conservation Sciences, Manomet, Massachusetts, USA.

Fernández, G., N. Warnock, D. B. Lank, and J. B. Buchanan. 2010b. Conservation plan for the Western Sandpiper (Calidris mauri). Version 1.1. Manomet Center for Conservation Sciences, Manomet, Massachusetts, USA.

Galbraith, H., R. Jones, R. Park, J. Clough, S. Herrod-Julius, B. Harrington, and G. Page. 2002. Global climate change and sea level rise: potential losses of intertidal habitat for shorebirds. Waterbirds 25:173-183. https://doi.org/10.1675/1524-4695(2002) 025[0173:GCCASL]2.0.CO;2

Garcia Walther, J., N. Senner, H. V. Norambuena, and F. Schmitt. 2017. Atlas de las aves playeras de Chile. National Audubon Society, New York and Cornell Lab of Ornithology, Ithaca, New York, USA.

Gardali, T., N. E. Seavy, R. T. DiGaudio, and L. A. Comrack. 2012. A climate change vulnerability assessment of California's at-risk birds. PLoS ONE 7(3):e29507. https://doi.org/10.1371/ journal.pone.0029507

Gelman, A., and J. Hill. 2007. Data analysis using regression and multilevel/hierarchical models. Cambridge University Press, New York, New York, USA. https://doi.org/10.1017/CBO9780511790942

Gibson, D., M. K. Chaplin, K. L. Hunt, M. J. Friedrich, C. E. Weithman, L. M. Addison, V. Cavalieri, S. Coleman, F. J. Cuthbert, J. D. Fraser, W. Golder, D. Hoffman, S. M. Karpanty, A. Van Zoeren, and D. H. Catlin. 2018. Impacts of anthropogenic disturbance on body condition, survival, and site fidelity of nonbreeding Piping Plovers. Condor 120:566-580. https://doi. org/10.1650/CONDOR-17-148.1

Gitzen, R. A., J. J. Millspaugh, A. B. Cooper, and D. S. Licht, editors. 2012. Design and analysis of long-term ecological monitoring studies. Cambridge University Press, Cambridge, UK. https://doi.org/10.1017/CBO9781139022422

Green, R. E., A. Balmford, P. R. Crane, G. M. Mace, J. D. Reynolds, and R. K. Turner. 2005. A framework for improving monitoring of biodiversity: responses to the World Summit on Sustainable Development. Conservation Biology 19:56-65. https:// doi.org/10.1111/j.1523-1739.2005.00289.x 
Heisey, D. M., E. E. Osnas, P. C. Cross, D. O Joly, J. A Langenberg, and M. W Miller. 2010. Linking process to pattern: estimating spatiotemporal dynamics of a wildlife epidemic from crosssectional data. Ecological Monographs 80:221-240. https://doi. org/10.1890/09-0052.1

Iwamura T., H. P. Possingham, I. Chadès, C. Minton, N. J. Murray, D. I. Rogers, E. A. Treml, and R. A. Fuller. 2013. Migratory connectivity magnifies the consequences of habitat loss from sea-level rise for shorebird populations. Proceedings of the Royal Society B 280:20130325. http://dx.doi.org/10.1098/ rspb.2013.0325

Johnston-González, R., and E. Abril. 2019. Predation risk and resource availability explain roost locations of Whimbrel Numenius phaeopus in a tropical mangrove delta. Ibis 161:839-853. https://doi.org/10.1111/ibi.12678

Johnston-González, R., and D. Eusse-Gonzalez. 2009. Sitios importantes para aves playeras en Colombia. Asociación Calidris, Cali, Colombia.

Johnston-González, R., C. J. Ruiz-Guerra, D. Eusse-Gonzalez, L. F. Castillo, Y. Cifuentes Sarmiento, P. Falk-Fernandez, and V. Ramirez de los Rios. 2010. Plan de Conservación para aves Playeras en Colombia, Lineamientos Técnicos. Asociación Calidris, Cali, Colombia.

Kaufmann, K., R. Miró, Y. Díaz, M. Caballero, and S. Carty. 2018. Monitoring winter shorebird populations in the Bay of Panama: 2013-2017. Wader Study 125:97-106. https://doi. org/10.18194/ws.00118

Kincaid, T. M., and A. R. Olsen. 2017. spsurvey: Spatial survey design and analysis. $R$ package version 3.4.

Lank, D. B., R. W. Butler, J. Ireland, and R. C. Ydenberg. 2003. Effects of predation danger on migration strategies of sandpipers. Oikos 103:303-319. https://doi.org/10.1034/j.1600-0706.2003.12314. $\mathrm{x}$

Martin, T. G., I. Chadès, P. Arcese, P. P. Marra, H. P. Possingham, and D. R. Norris. 2007. Optimal conservation of migratory species. PLoS ONE 2(8):e751. https://doi.org/10.1371/journal. pone. 0000751

Moilanen, A. 2007. Landscape zonation, benefit functions and target-based planning: unifying reserve selection strategies. Biological Conservation 134:571-579. https://doi.org/10.1016/j. biocon.2006.09.008

Moran, P. A. P. 1950. Notes on continuous stochastic phenomena. Biometrika 37:17-23. https://doi.org/10.1093/biomet/37.1-2.17

Morrison, R. I. G. 1984. Migration systems of some New World shorebirds. Pages 125-202 in J. Burger and B. L. Olla, editors, Shorebirds: migration and foraging behavior. Behavior of Marine Animals: Current Perspectives in Research 6 Plenum Press, New York, New York, USA.

Morrison, R. I. G., R. W. Butler, F. S. Delgado, and R. K. Ross. 1998. Atlas of Nearctic shorebirds and other waterbirds on the coast of Panama. Special Publication. Canadian Wildlife Service, Ottawa, Ontario, Canada.
Morrison, R. I. G., and K. A. Hobson. 2004. Use of body stores in shorebirds after arrival on high-arctic breeding grounds. Auk 121:333-344. https://doi.org/10.1093/auk/121.2.333

Morrison, R. I. G., and R. K. Ross. 1989. Atlas of Nearctic shorebirds on the coast of South America. Canadian Wildlife Service Special Publication, Ottawa, Ontario, Canada.

Murray, N. J., S. R. Phinn, M. DeWitt, R. Ferrari, R. Johnston, M. B. Lyons, N. Clinton, D. Thau, and R. A. Fuller. 2019. The global distribution and trajectory of tidal flats. Nature 565:222-225. https://doi.org/10.1038/s41586-018-0805-8

NatureServe. 2017. NatureServe Web Service. Arlington, Virginia, USA. [online] URL: http://services.natureserve.org.

Navedo, J. G., G. Fernández, J. Fonseca, and M. C. Drever. 2015. A potential role of shrimp farms for the conservation of Nearctic shorebird populations. Estuaries and Coasts 38:836-845. https:// doi.org/10.1007/s12237-014-9851-0

Neuman, K. K., L. A. Henkel, and G. W. Page. 2008. Shorebird use of sandy beaches in central California. Waterbirds 31:115-121. https://doi.org/10.1675/1524-4695(2008)31[115:SUOSBI]2.0.CO;2

Page, G. W., L. E. Stenzel, and J. E. Kjelmyr. 1999. Overview of shorebird abundance and distribution in wetlands of the Pacific coast of the contiguous United States. Condor 101:461-471. https://doi.org/10.2307/1370176

Page, G. W., and D. F. Whitacre. 1975. Raptor predation on wintering shorebirds. Condor 77:173-183. https://doi.org/10.2307/1366760

Peters, K. A., and D. L. Otis. 2007. Shorebird roost-site selection at two temporal scales: Is human disturbance a factor? Journal of Applied Ecology 44:196-209. https://doi.org/10.1111/

j.1365-2664.2006.01248.x

Pfister, C., B. A. Harrington, and M. Lavine. 1992. The impact of human disturbance on shorebirds at a migration staging area. Biological Conservation 60:115-126. https://doi.org/10.1016/0006-3207 (92)91162-L

Pomeroy, A. C. 2006. Tradeoffs between food abundance and predation danger in spatial usage of a stopover site by western sandpipers, Calidris mauri. Oikos 112:629-637. https://doi. org/10.1111/j.0030-1299.2006.14403.x

Pomeroy, A. C., D. A. Acevedo Seaman, R. W. Butler, R. W. Elner, T. D. Williams, and R. C. Ydenberg. 2008. Feeding-danger tradeoffs underlie stopover site selection by migrants. Avian Conservation and Ecology - Écologie et conservation des oiseaux 3 (1):7. https://doi.org/10.5751/ace-00240-030107

Pomeroy, A. C., R. W. Butler, and R. C. Ydenberg. 2006. Experimental evidence that migrants adjust usage at a stopover site to trade off food and danger. Behavioral Ecology 17:1041-1045. https://doi.org/10.1093/beheco/ar1043

Reiter, M. E., N. K. Elliott, D. Jongsomjit, G. H. Golet, and M. D. Reynolds. 2018. Impact of extreme drought and incentive programs on flooded agriculture and wetlands in California's Central Valley. PeerJ 6:e5147. https://doi.org/10.7717/peerj.5147

Reiter, M. E., N. Elliott, S. Veloz, D. Jongsomjit, C. M. Hickey, M. Merrifeld, and M. Reynolds. 2015. Spatio-temporal patterns 
of open surface water in the Central Valley of California 2000-2011: drought, land cover, and waterbirds. Journal of the American Water Resources Association 51:1722-1738. https:// doi.org/10.1111/1752-1688.12353

Reiter, M. E., C. M. Hickey, G. W. Page, W. D. Shuford, and K. M. Strum. 2011a. A monitoring plan for wintering shorebirds in the Central Valley of California, version 1.0. Report to the California Landscape Conservation Cooperative. PRBO Conservation Science, Petaluma, California, USA.

Reiter, M. E., C. M. Hickey, G. W. Page, and J. Wood. 2011b. A monitoring plan for wintering shorebirds in San Francisco Bay, $v$. 1.0. Report to the California Landscape Conservation Cooperative. PRBO Conservation Science, Petaluma, California, USA.

Reiter, M. E., W. D. Shuford, K. M. Strum, C. M. Hickey, and G. W. Page. 2012. A monitoring plan for wintering shorebirds in coastal California and northern Baja California, Mexico, version 1.0. Report to the California Landscape Conservation Cooperative. PRBO Conservation Science, Petaluma, California, USA.

Sandoval, L., and C. Sanchez, editors. 2011. Important bird areas of Costa Rica. Unión de Ornitólogos de Costa Rica, San José, Costa Rica.

Secretaría de Medio Ambiente y Recursos Naturales (SEMARNAT). 2008. Estrategia para la conservación y manejo de las aves playeras y sus hábitat en México. SEMARNAT, México City, México. [online] URL: http://www.dumac.org/ dumac/habitat/esp/pdf/AvesPlayeras.pdf

Senner, N. R., and F. Angulo Pratolongo. 2014. Atlas de las aves playeras del Perú: Sitios importantes para su conservación. CORBIDI, Lima, Peru.

Senner, S. E., B. A. Andres, and H. R. Gates, editors. 2016. Pacific Americas shorebird conservation strategy. National Audubon Society, New York, New York, USA. [online] URL: https:// pacificflywayshorebirds.org/downloads/PASCSv2_english_final. pdf

Shuford, W. D., G. W. Page, and J. E. Kjelmyr. 1998. Patterns and dynamics of shorebird use of California's Central Valley. Condor 100:227-244. https://doi.org/10.2307/1370264

Shuford, W. D., N. Warnock, K. C. Molina, and K. K. Sturm. 2002. The Salton Sea as critical habitat to migratory and resident waterbirds. Hydrobiologia 473:255-274. https://doi.org/10.1023/ A:1016566709096

Stevens, D. L., and A. R. Olsen. 2004. Spatially balanced sampling of natural resources. Journal of the American Statistical Association 99:262-278. https://doi.org/10.1198/016214504000000250

Strum, K. M., M. J. Hooper, K. A. Johnson, R. B. Lanctot, M. E. Zaccagnini, and B. K. Sandercock. 2010. Exposure of nonbreeding migratory shorebirds to Cholinesterase inhibiting contaminants in the Western Hemisphere. Condor 112:15-28. https://doi.org/10.1525/cond.2010.090026
Strum, K., M. E. Reiter, C. A. Hartman, M. N. Iglecia, T. R. Kelsey, and C. M. Hickey. 2013. Winter management of California's rice fields to maximize waterbird habitat and minimize water use. Agriculture, Ecosystems, \& Environment 179:116-124. https://doi.org/10.1016/j.agee.2013.08.003

Sutherland, W. J., J. A. Alves, T. Amano, C. H. Chang, N. C. Davidson, C. M. Finlayson, J. A. Gill, R. E. Gill Jr, P. M. González, T. G. Gunnarsson, et al. 2012. A horizon scanning assessment of current and potential future threats facing migratory shorebirds. Ibis 154:663-679. https://doi.org/10.1111/ j.1474-919X.2012.01261.x

U.S. Shorebird Conservation Plan Partnership (USSCPP). 2016. U.S. shorebirds of conservation concern in the United States of America - 2016. U.S. Shorebird Conservation Plan Partnership. https://www.shorebirdplan.org/wp-content/uploads/2016/08/ShorebirdsConservation-Concern-2016.pdf

Veloz, S. D., N. Nur, L. Salas, D. Jongsomjit, J. Wood, D. Stralberg, and G. Ballard. 2013. Modeling climate change impacts on tidal marsh birds: restoration and conservation planning in the face of uncertainty. Ecosphere 4(4):1-25. http:// dx.doi.org/10.1890/ES12-00341.1

Warnock, N. E., G. W. Page, and L. E. Stenzel. 1995. Nonmigratory movements of Dunlins on their California wintering grounds. Wilson Bulletin 107:131-139.

Wilen, B. O., and M. K. Bates. 1995. The US Fish and Wildlife Service's National Wetland Inventory Project. Vegetatio 118:153-169. https://doi.org/10.1007/BF00045197

Williams, B. K., J. D. Nichols, and M. J. Conroy. 2002. Analysis andmanagement of animal populations: modeling, estimation, and decision making. Academic, San Diego, California, USA.

Wood, J., G. Page, M. Reiter, L. Liu, and C. Robinson-Nilsen. 2010. Abundance and distribution of wintering shorebirds in San Francisco Bay, 1990-2008: population change and informing future monitoring. Report to the Resource Legacy Fund. PRBO Conservation Science, Petaluma, California, USA.

Xu, C., J. Barrett, D. B. Lank, and R. C. Ydenberg. 2015. Large and irregular population fluctuations in migratory Pacific (Calidris alpina pacifica) and Atlantic (C. a. hudsonica) Dunlins are driven by density-dependence and climatic factors. Population Ecology 57:551-567. https://doi.org/10.1007/ s10144-015-0502-5

Yasué, M., and P. Dearden. 2009. The importance of supratidal habitats for wintering shorebirds and the potential impacts of shrimp aquaculture. Environmental Management 43:1108. https://doi.org/10.1007/s00267-008-9255-7

Ydenberg, R. C., J. Barrett, D. B. Lank, C. Xu, and M. Faber. 2017. The redistribution of non-breeding Dunlins in response to the post-DDT recovery of falcons. Oecologia 183:1101-1110. https://doi.org/10.1007/s00442-017-3835-2

Zharikov, Y., and D. A. Milton. 2009. Valuing coastal habitats: predicting high-tide roosts of non-breeding migratory shorebirds from landscape composition. Еmu 109:107-120. https://doi.org/10.1071/MU08017 
Zuur, A. F., E. N. Ieno, N. Walker, A. A. Saveliev, and G. M. Smith. 2009. Mixed effects models and extensions in ecology with $R$. Springer, New York, New York, USA. https://doi. org/10.1007/978-0-387-87458-6

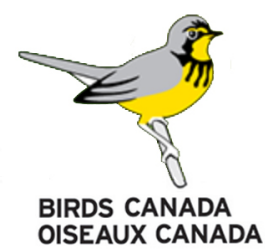


Appendix 1: Hypotheses of factors influencing the distribution and abundance of wintering and migrating Western Sandpipers (Calidris mauri; WESA) and Dunlin (Calidris alpina pacifica; DUNL) and implication for large-scale study design. $\mathrm{H}=$ hypothesis; $\mathrm{P}=$ prediction; $\mathrm{SD}=$ study design; $\mathrm{D}=$ data; $\mathrm{A}=$ analysis

\begin{tabular}{|c|c|c|}
\hline Climate Change & Survey Design / Data / Analysis & Management / Conservation \\
\hline $\begin{array}{l}\text { H1: Increasing temperatures will provide } \\
\text { more available winter food resources in } \\
\text { northern coastal estuaries and non- } \\
\text { coastal agricultural habitats. } \\
\text { P1: Long-term Response: As } \\
\text { climate warms shorebirds will } \\
\text { over-winter further north and } \\
\text { use more interior agricultural } \\
\text { habitats. } \\
\text { P2: Short-term Response: Use } \\
\text { by DUNL and WESA in years } \\
\text { following warm winter will } \\
\text { increase at northern estuaries. }\end{array}$ & $\begin{array}{l}\text { SD: Need latitudinal gradient of wintering estuary surveys } \\
\text { including sites both north and south of current wintering range } \\
\text { (e.g. Alaska, Chile, Brazil) } \\
\text { SD: Need both coastal and interior monitoring site } \\
\text { D: Quantify "warm" winter in prior year } \\
\quad \text { - Average daily high (Nov - Feb) } \\
\text { D: Winter survey in AK and BC - Feb) } \\
\text { A: Fit model with interaction between latitudinal strata and year } \\
\text { A: Perhaps lag-effect from previous winter. }\end{array}$ & $\begin{array}{l}\text { Predict hotspots of wintering shorebirds in } \\
\text { a future landscape to inform how to } \\
\text { optimize conservation action and } \\
\text { management. }\end{array}$ \\
\hline $\begin{array}{l}\text { H2: Sea-level rise and changing water } \\
\text { regimes will reduce available habitat and } \\
\text { lead to a re-distribution } \\
\text { P1: Estuaries with low tidal } \\
\text { gradient combined with steep } \\
\text { surrounding terrestrial } \\
\text { topography will be impacted }\end{array}$ & $\begin{array}{l}\text { SD: Need sample of sites along the tidal gradient and surrounding } \\
\text { topography. } \\
\text { A: Employ bird use and habitat data from surveys and sea-level } \\
\text { rise projections to predict the impact of SLR on shorebird } \\
\text { populations. }\end{array}$ & $\begin{array}{l}\text { Provide vulnerability assessment of coastal } \\
\text { estuaries along the Pacific Coast to the } \\
\text { impact of sea-level rise in the context of } \\
\text { tidal flat dependent species. }\end{array}$ \\
\hline
\end{tabular}




\begin{tabular}{|c|c|c|}
\hline $\begin{array}{l}\text { greater than higher tidal } \\
\text { gradient and lower surrounding } \\
\text { terrestrial topography. }\end{array}$ & $\begin{array}{l}\text { D: Need SLR projections for set of sites as well as specific habitats } \\
\text { that are needed by shorebirds. }\end{array}$ & \\
\hline Predators & Design and Data & Management / Conservation \\
\hline $\begin{array}{l}\text { H1: Increases in the abundance of birds } \\
\text { of prey has resulted in changes in } \\
\text { migratory behaviour or shorebirds and } \\
\text { possibly changes in use of wintering } \\
\text { grounds. } \\
\text { P1: We predict higher use of } \\
\text { large, open sites (i.e. safer) } \\
\text { versus small and dangerous } \\
\text { sites (Taylor et al. 2007). } \\
\text { P2: We predict higher use of } \\
\text { sites with lower probability of } \\
\text { predator occurrence. } \\
\text { P3: We predict sites with } \\
\text { increasing predator abundance } \\
\text { will have lower shorebird } \\
\text { growth rates than sites with } \\
\text { stable or decreasing predator } \\
\text { abundance. }\end{array}$ & $\begin{array}{l}\text { SD: Need sample of "safe" and "dangerous" sites } \\
\quad \text { - Average distance to shore for estuary as index of site } \\
\text { safety. } \\
\text { D: Count predators: evaluate and control for predator pressure } \\
\text { variation among sites } \\
\text { D: Record start and end times of surveys and the number of avian } \\
\text { predators seen. } \\
\text { A: Control for different amounts of foraging habitat within each } \\
\text { estuary site } \\
\text { D: Calculate safety index for all estuary sites in Western } \\
\text { sandpiper and Dunlin wintering range }\end{array}$ & $\begin{array}{l}\text { Identify the distribution of safe to unsafe } \\
\text { estuary sites for wintering sandpipers. } \\
\text { "Dangerous" sites within closer proximity } \\
\text { to safe sites may be better able to sustain } \\
\text { shorebirds amid annual variation and long } \\
\text { term trends in predator abundance. } \\
\text { Management could be used to maximize } \\
\text { safety within a site. }\end{array}$ \\
\hline $\begin{array}{l}\text { H2: Shorebirds have become more } \\
\text { numerous in non-coastal areas which } \\
\text { have fewer predators. }\end{array}$ & $\begin{array}{l}\text { SD: Need sample of sites that represent coastal and non-coastal } \\
\text { gradient }\end{array}$ & $\begin{array}{l}\text { Identify important sites for wintering } \\
\text { shorebirds that are non-coastal. }\end{array}$ \\
\hline
\end{tabular}




\begin{tabular}{|c|c|c|}
\hline $\begin{array}{l}\text { P1: Shorebird depart relatively } \\
\text { dangerous coastal sites for safer } \\
\text { non-costal sites. Trend of } \\
\text { increasing abundance of } \\
\text { shorebirds in non-coastal } \\
\text { regions compared to coastal } \\
\text { areas. } \\
\text { P2: Higher probability of raptors } \\
\text { in coastal areas compared to } \\
\text { non-coastal. }\end{array}$ & $\begin{array}{l}\text { D: Count predators: evaluate and control for predator pressure } \\
\text { variation among sites } \\
\text { A: Density control for different amounts of foraging habitat } \\
\text { within each estuary site }\end{array}$ & $\begin{array}{l}\text { Provide recommendations to land } \\
\text { managers about the spatial and temporal } \\
\text { variation in shorebird use of their regions. }\end{array}$ \\
\hline Contamination & Survey Design and Data & Management / Conservation \\
\hline $\begin{array}{l}\text { H1: Shorebirds accumulate industrial and } \\
\text { urban pollution at wintering sites that } \\
\text { are subsequently released in sudden high } \\
\text { doses as fat is burned during migratory } \\
\text { flights that then disrupt their ability } \\
\text { survive and reproduce. }\end{array}$ & $\begin{array}{l}\text { SD: Need sample of sites representing gradient of contamination. } \\
\text { SD: Need method to assess contamination level at site. } \\
\text { A: Are tidal flats closer to distance to river inputs associated with } \\
\text { higher contamination and subsequently less use by shorebirds? }\end{array}$ & $\begin{array}{l}\text { Demonstrate the distribution of } \\
\text { contaminants and its effect on the } \\
\text { distribution of shorebirds both within and } \\
\text { among estuary sites. } \\
\text { Identify hotspots of contamination in the } \\
\text { flyway and provide recommendations for } \\
\text { limiting contamination sources. }\end{array}$ \\
\hline Human Disturbance & Survey Design and Data & Management / Conservation \\
\hline $\begin{array}{l}\text { H1: Human disturbance at wintering sites } \\
\text { reduces the time available for shorebirds } \\
\text { to accumulate fat for migration and } \\
\text { subsequently could impact survival and } \\
\text { productivity. }\end{array}$ & $\begin{array}{l}\text { SD: Need sample of sites with varying levels of human } \\
\text { disturbance during winter. }\end{array}$ & $\begin{array}{l}\text { Human management recommendations if } \\
\text { disturbance shown to lead to decreases in } \\
\text { site use. }\end{array}$ \\
\hline
\end{tabular}




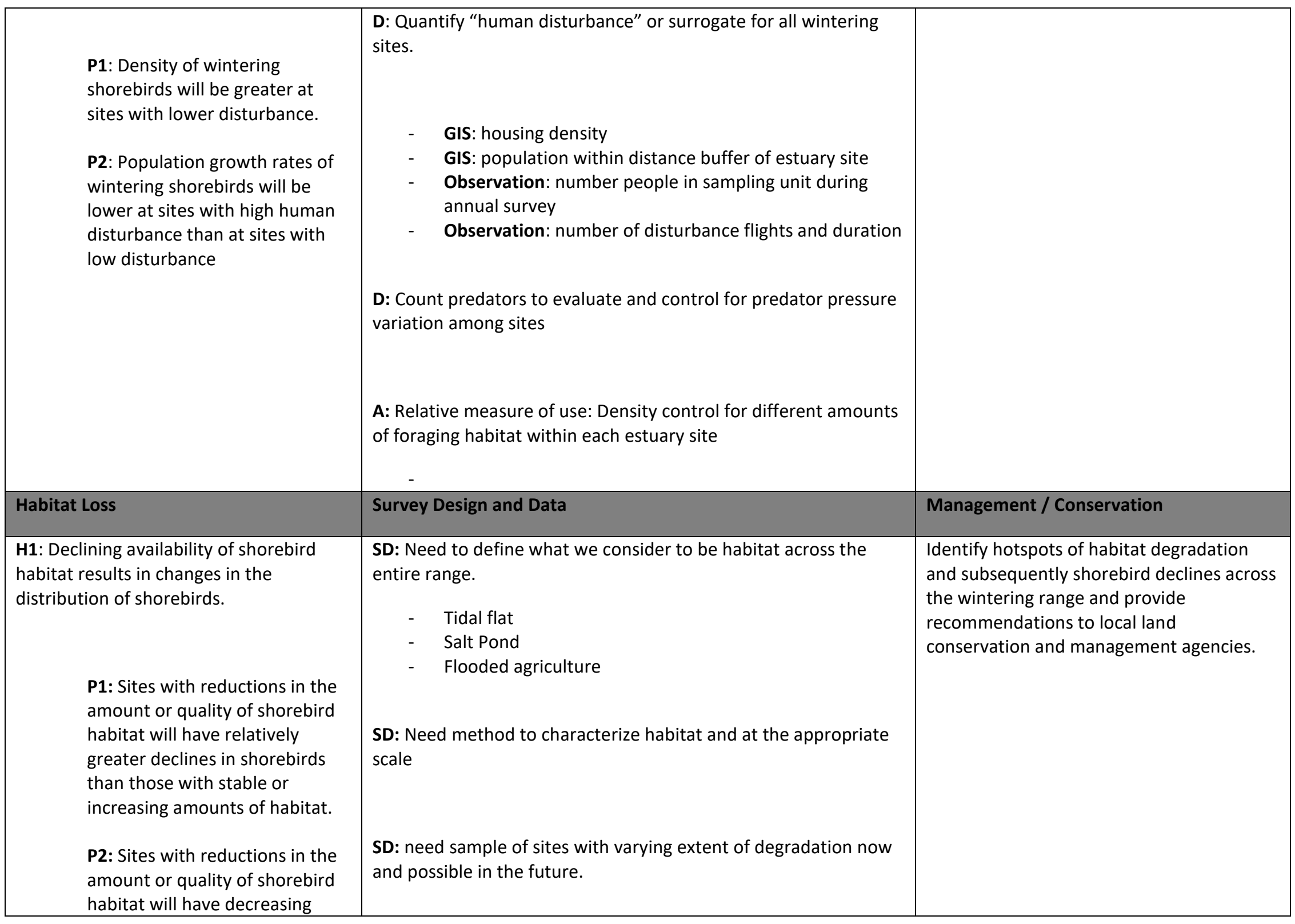




\begin{tabular}{|l|l|}
\hline $\begin{array}{l}\text { turnover times during } \\
\text { migration. }\end{array}$ & D: Quantify "habitat" \\
$-\quad$ GIS: Tidal flat, Salt Pond, Agriculture \\
$-\quad$ Observation: soil sample - biomass, grain size \\
D: Quantify "degradation" \\
$-\quad$ GIS: change in acres of tidal flat \\
$-\quad$ Observation: change in food availability (requires \\
$-\quad$ multiple surveys of food over course of project) \\
A: Compare time series of bird counts to index of habitat quantity \\
and quality over time
\end{tabular} \mid

